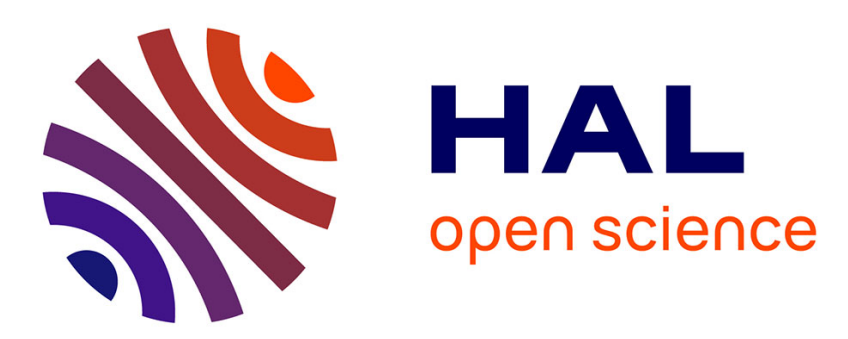

\title{
Ionising radiation and area-wide management of insect pests to promote sustainable agriculture. A review \\ Marc Vreysen, Alan Robinson
}

\section{To cite this version:}

Marc Vreysen, Alan Robinson. Ionising radiation and area-wide management of insect pests to promote sustainable agriculture. A review. Agronomy for Sustainable Development, 2011, 31 (1), pp.233250. 10.1051/agro/2010009 . hal-00930471

\section{HAL Id: hal-00930471 https://hal.science/hal-00930471}

Submitted on 1 Jan 2011

HAL is a multi-disciplinary open access archive for the deposit and dissemination of scientific research documents, whether they are published or not. The documents may come from teaching and research institutions in France or abroad, or from public or private research centers.
L'archive ouverte pluridisciplinaire HAL, est destinée au dépôt et à la diffusion de documents scientifiques de niveau recherche, publiés ou non, émanant des établissements d'enseignement et de recherche français ou étrangers, des laboratoires publics ou privés. 


\title{
Review article
}

\section{Ionising radiation and area-wide management of insect pests to promote sustainable agriculture. A review}

\author{
Marc J.B. VREYSEN*, Alan S. ROBINSON \\ Entomology Unit, FAO/IAEA Agriculture and Biotechnology Laboratory, Joint FAO/IAEA Programme, Vienna, Austria
}

(Accepted 11 February 2010)

\begin{abstract}
Despite the liberal use of broad-spectrum insecticides to keep many insect pests of agricultural and veterinary importance at bay, food losses, both pre- and post-harvest, due to these insect pests contribute significantly to the high prevalence of undernourishment in the world. New, innovative pest control tactics and strategies are therefore needed that are both effective and not detrimental to the environment. As part of the arsenal of environmentally-friendly control tactics, the sterile insect technique (SIT) has proven to be a very effective tool against selected insect pests when used as part of an area-wide integrated pest management (AW-IPM) approach. Likewise, the use of natural enemies for augmentative or inundative biological control is now a major component of pest control in many parts of the world. Both control tactics are complementary and even synergistic under certain circumstances, but their combined use has so far not been applied on an operational scale. Ionising radiation can be readily employed to effectively and safely induce sexual sterility in insects. Although the sterile insect technique has often been associated with an eradication strategy, major advances in rearing efficiency, and improved handling and release methods, have made the use of sterile insects economically feasible for insect pest suppression, prevention or containment. Recently, more emphasis has been placed on the quality of the sterile insect once released in the field rather than mainly assessing quality in the rearing facility. This combined with other innovations such as the development of genetic sexing strains, better understanding the impact of radiation on radio-resistant species such as Lepidoptera and the development of the $F_{1}$ sterility concept, advances in monitoring the induced sterility, etc. have significantly increased the efficiency of the sterile insect technique for several insect species. The action of sterile insects is inversely dependent on the density of the target population, and sterile insects have the intrinsic capacity to actively search for and mate with the last individuals of a pest population. These two characteristics make them ideal to deal with outbreaks of invasive insect pests. The use of sterile insects presents no threat to the environment, but aspects such as diet and waste disposal in large rearing facilities or bio-security in cases where the rearing facility is located in an area that is already free of the pest require the necessary attention. Ionising radiation can also be applied to greatly improve the efficiency of mass-rearing, handling and shipment of insect parasitoids and predators. Area-wide integrated pest management programmes that use sterile insects or natural enemies are complex and management-intensive, and require a management structure that is exclusively dedicated to the programme. Past and current examples have shown the enormous benefit-cost ratios that these programmes can generate and their importance for enhanced agriculture is increasing in significance.
\end{abstract}

natural enemies / sterile insect technique / area-wide integrated pest management / economic benefits

\section{Contents}

1 Introduction: insecticide use and food security $\ldots \ldots \ldots \ldots \ldots \ldots \ldots$

2 Area-wide integrated pest management (AW-IPM) ............ 2

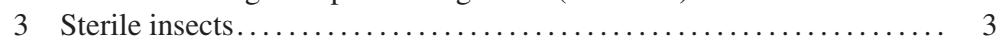

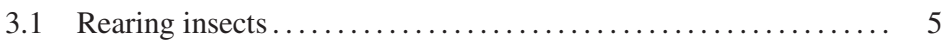

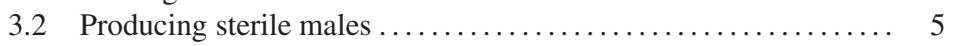

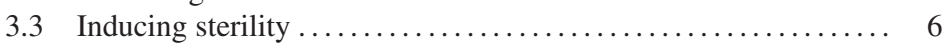

3.4 Sterile insect quality management $\ldots \ldots \ldots \ldots \ldots \ldots \ldots \ldots \ldots$

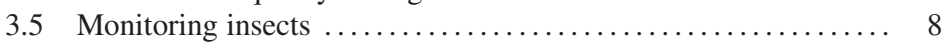

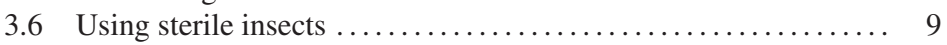

4 Ionising radiation and natural enemies $\ldots \ldots \ldots \ldots \ldots \ldots \ldots \ldots \ldots$

*Corresponding author: M.Vreysen@iaea.org 


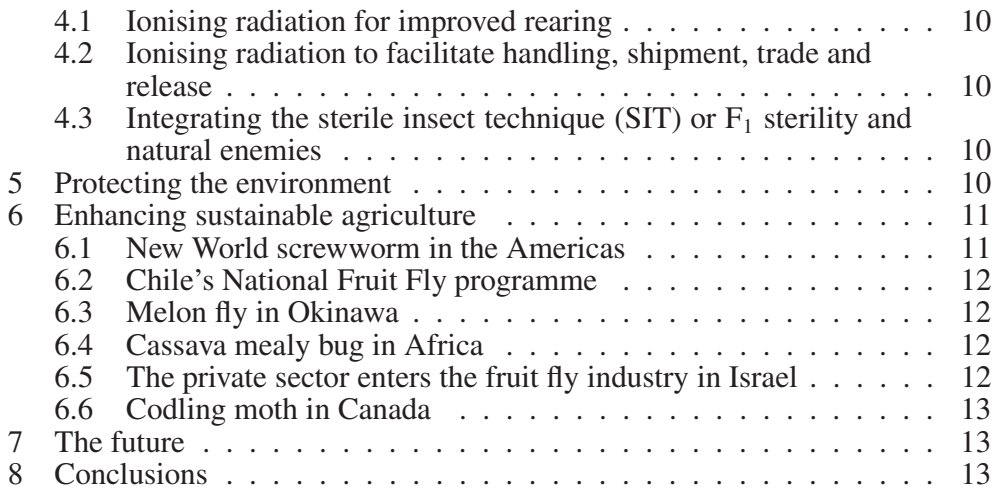

\section{INTRODUCTION: INSECTICIDE USE AND FOOD SECURITY}

Although the prevalence of undernourishment (i.e. those people whose dietary energy consumption is continuously below a minimum dietary energy requirement for maintaining a healthy life and carrying out light physical activity with an acceptable minimum body-weight for attained height) has declined worldwide from $18 \%$ in $1990-1992$ to $13 \%$ in $2003-$ 2005 , the total number of undernourished people in the world has remained constant, or has even slightly increased (841 million in 1990-1992 to 848 million in 2003-2005) (FAO, 2008). Even in the developed world, the Food and Agriculture Organization of the United Nations (FAO) estimates that more than 15 million people remain undernourished, and the US Department of Agriculture (USDA) estimates that 36.2 million US citizens, including 12.4 million children, were foodinsecure in 2007 (US Working Group on the Food Crisis, 2009). In 2003-2005, the food deficit of the undernourished population was $90-110 \mathrm{kcal} /$ person/day in countries such as Israel, Luxembourg, Canada, Norway, etc., but between 350 and $440 \mathrm{kcal} /$ person/day in Liberia, Eritrea, Burundi, Sierra Leone, Haiti and the Democratic Republic of Congo (FAO, 2008).

Insect pests that harm livestock and damage crops, both pre- and post-harvest, are often at the root of food insecurity, with more than 10000 insect and mite pests described. To keep these pests at bay, farmers use three million metric tons of insecticides annually at a cost of USD 35000 million (Pimentel, 2007). In Europe alone, more than 140000 tonnes of pesticides are sprayed on food crops every year, which corresponds to 280 grams/EU citizen/year (Reuters, 2008). Rising concerns about pesticide residues in food commodities, as well as increased resistance of many pest insects to insecticides, contamination of the environment and outbreaks of secondary pests, have compelled the EU to call for a ban on aerial cropspraying of 22 toxic chemicals by 2016 (United Press International, 2008). Therefore, enhancing more efficient livestock and crop production systems requires the development and implementation of insect pest control methods and strategies that are more effective, more target-specific, and which have minimal impact on the environment. During the last decades, numerous environmentally-friendly surrogates for the use of broad-spectrum synthetic insecticides have been developed, but their wide application has not always been straightforward as some of these techniques, such as mating disruption for lepidopteran pests (Cardé and Minks, 1995) or the sterile insect technique (SIT) (Dyck et al., 2005), require application on an area-wide basis (see below) (Vreysen et al., 2007a; Koul et al., 2008). Especially in Europe, farmers are very individualistic in their approach to pest control, and area-wide practices have not gained the same level of importance as in other continents. In the last decades, it has become clear that the careful selection of control tactics and their appropriate application and combination in space and time results in most cases in more effective pest control and thus enhanced sustainable agriculture (Vreysen et al., 2007a).

\section{AREA-WIDE INTEGRATED PEST MANAGEMENT (AW-IPM)}

Many years ago, the innovative Knipling (1959, 1972, 1979) used simple mathematical models to show the importance of applying pest control techniques on an area-wide basis, targeting the entire pest population within a defined area, as opposed to a field-by-field approach where portions of the pest population are left untouched. In one of his models, he compared two areas with equivalent populations undergoing a five-fold natural rate of increase per year. In one area, $99 \%$ of $90 \%$ of the pest population is destroyed each year (but no control is conducted on the remaining 10\%) while in the other area the control is less intense, eliminating only $90 \%$ of the pest population but from the total area (100\%) each year. Following five years of these treatments in the two areas the model indicates that there would be 100 times more pests in the first area than in the second (Fig. 1). Exercising less intensive control against the total pest population is therefore more effective than subjecting only part of the population to more intensive control efforts (Klassen, 2005). These calculations, however oversimplified, illustrate how critical it is to consider the total pest population (area-wide population control or total population control) in operational planning of pest control activities and how devastating the recruitment of individuals from relic foci can be for the control effort (Knipling, 1979; Hendrichs et al., 2007). This paper will focus on the use of biological 

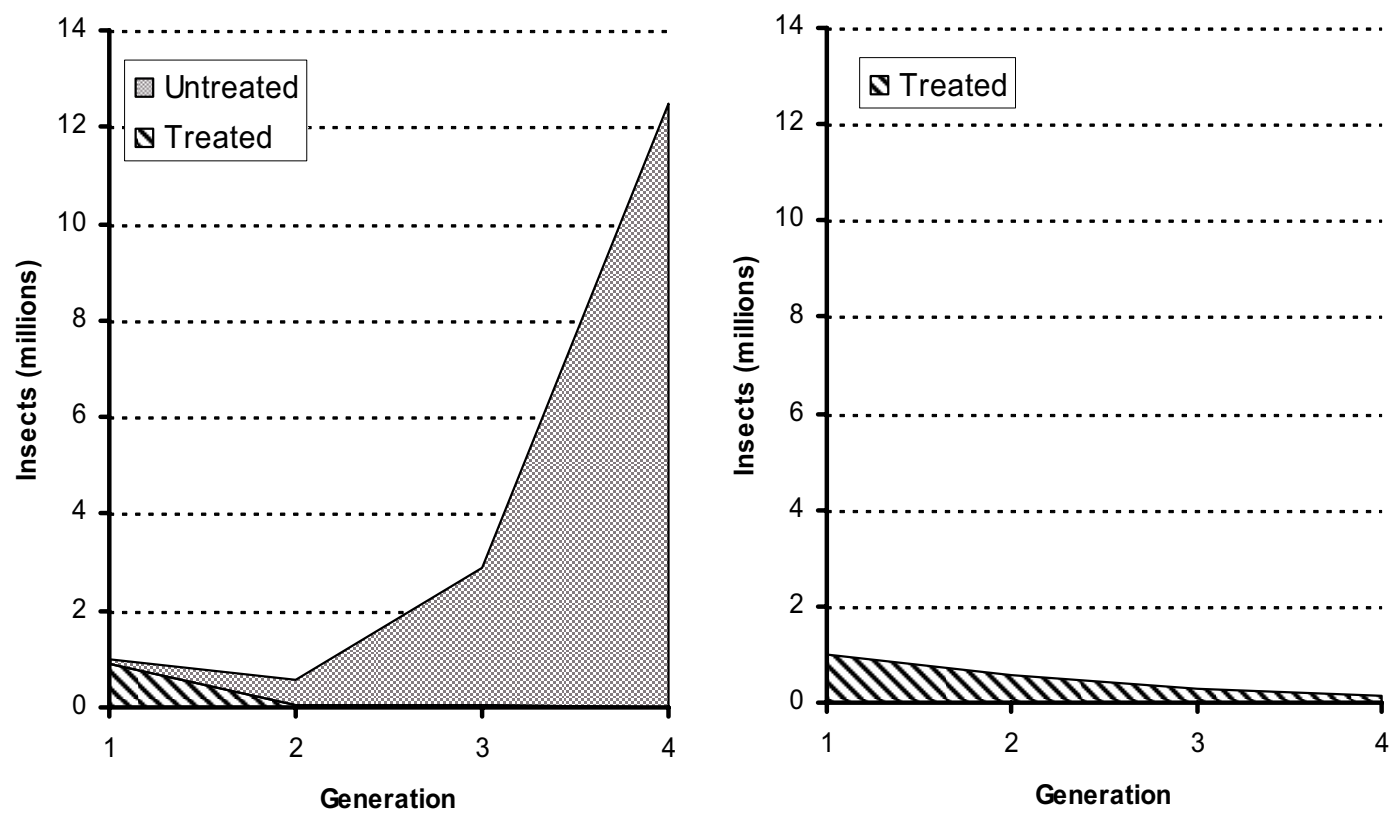

Figure 1. (Right) the effect of total population control (less intense control (90\%) on the total (100\%) population) on the size and growth of a hypothetical insect population as compared with (left) a strategy where only part of the population is subjected to control ( $99 \%$ control on $90 \%$ of the population) (Modified after Knipling, 1979).

control agents, namely sterile insects and natural enemies, in area-wide integrated pest management programmes and illustrate the use of ionising radiation in the application of these biological control agents. Sterile insects were not previously considered biological control agents under the International Plant Protection Convention (IPPC) as they were not selfreplicating organisms, and were thus excluded from regulatory approval within the relevant International Standards for Phytosanitary Measures (ISPM). This situation changed in 2005 with the adoption by the IPPC of ISPM 3 "Guidelines for the Export, Shipment, Import and Release of Biological Control Agents and Other Beneficial Organisms" which recognised sterile insects as biological control agents (FAO, 2005).

Although sterile insects and natural enemies interact with the pest population in different ways, natural enemies by increasing daily mortality and sterile insects by reducing fertility, both kinds of agents must be distributed in the field on an area-wide basis. As well as sharing a similarity in the way they are applied, the biological control agents also have other components in common. The use of both biological control agents and sterile insects relies on efficient mass-rearing technology and on protocols to maintain strain quality. Both types of agents must be released in large numbers at regular intervals. Use of both kinds of agents requires effective monitoring of released and wild insects before, during and after releases. Finally, the use of both kinds of agents benefits from an ability to manipulate the sex ratio of the released insects. As well as these similarities, they also have the potential to act synergistically to reduce pest numbers when used in combination with each other (Knipling, 1966, 1972; Carpenter et al., 2005).

\section{STERILE INSECTS}

The use of sterile insects for pest control was conceived in 1937 and first applied in 1954, when there was little concern for environmental issues, sustainability and invasive species in relation to the control of agricultural pests (Knipling, 1955). In fact, the motivation to develop this technology came from the observation that a major pest of cattle in the USA, the New World screwworm Cochliomyia hominivorax (Coquerel), was present in the field at very low densities compared with other insect pests, which would make it vulnerable to introduction of sterility. Knipling's conceptual breakthrough was to realise that insect pests could be controlled by compromising their hereditary machinery and that the integrity of this machinery is critical for the survival of the insect. As is the case with many new concepts, "This approach to screwworm control was proposed to a number of scientists, but little enthusiasm for its possibilities was generated" (Knipling, 1959). Although the approach has gained much credibility in the intervening years (Krafsur, 1998) there are still many scientists and administrators who do not fully appreciate both the limitations and the potential of the technique (e.g. Vale and Torr, 2005). The concept was simple but revolutionary and, like most paradigm shifts, is obvious with hindsight.

The approach was a radical departure from the traditional methods of pest control, which usually relied on compromising the survival of insect pest populations through manipulation of the insect's environment using insecticides (Courschee, 1960), removal of hosts (Kovaleski, 2007), or other aspects critical for the survival of the insect (Ford et al., 1970). Also, in contrast to the traditional approaches, sterile insects have 


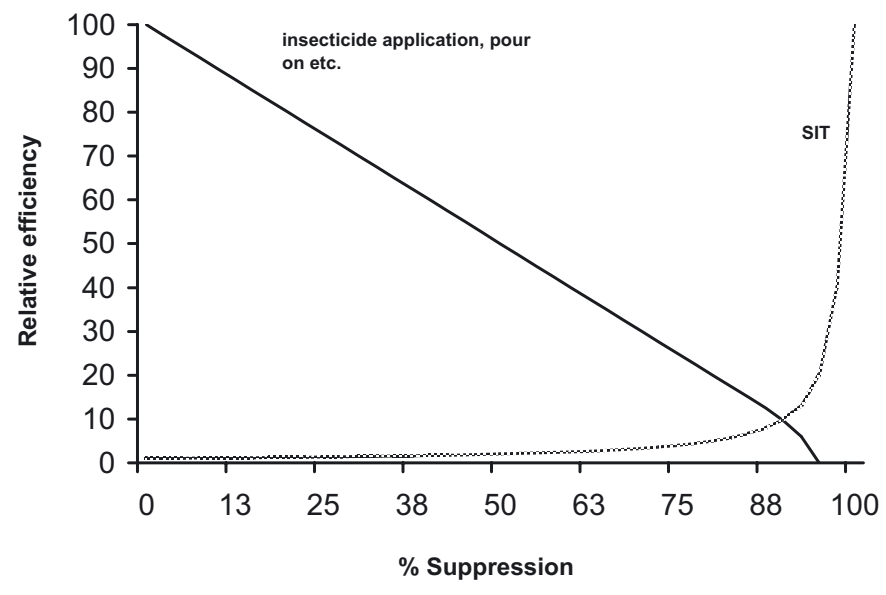

Figure 2. The effectiveness of various control tactics in relation to the density of the pest population (pour on = application of residual insecticides on livestock).

no immediate impact on the pest population as they do not directly kill the insects in the field. It was also the first time that a population of a given species was used to control or suppress a field population of the same species. The sterile insect technique is truly species-specific, in that it exerts its effect through conspecific matings of released sterile insects and their wild counterparts. Simply stated, the sterile insect technique is a form of birth control.

When sterile insects were first released on the island of Curaçao, they were used in the absence of other control methods as a stand-alone technique, in part to be able to measure their effectiveness without the complication of other confounding treatments (Baumhover et al., 1955). Subsequent experience has shown that this is rarely the case and to be effective, sterile insects must be integrated with other control tactics as part of area-wide integrated pest management programmes (see Fig. 2, inverse density dependence) (Vreysen et al., 2007a).

Each pest control tactic has its limitations, be they biological, operational, ethical, social, environmental, economic, etc., and in that respect, the use of sterile insects is not an exception. Sterile insects cannot be used for species where the stage to be released, usually the adult, is the one responsible for damage to the crop or livestock, i.e. insect vectors of diseases (e.g. horn flies - but see below), species where the adults are plant herbivores (e.g. locusts) and species where adults cause nuisance (e.g. house fly, cockroaches). A second limitation of the sterile insect technique is its substantial start-up and operational costs. Therefore, the application of the sterile insect technique is largely limited to use against very important key insect pests for which effective and affordable alternative controls are not available (Lance and McInnis, 2005). In some cases there is a value-added component, as controlling the key pest without the use of chemicals provides the opportunity for the secondary pest species to be regulated by their natural enemies. Economics will also play a key role related to the cost of rearing and releasing large numbers of sterile insects. Methods to artificially rear many species of insects have not yet been de- veloped, including for many species of beetles and weevils, the human botfly Dermatobia hominis (Linnaeus Jr.) and other parasites of mammals, and some insects with an obligatory diapause such as the western cherry fruit fly Rhagoletis indifferens Curran (Lance and McInnis, 2005).

Sterile insects can be used in several different types of programmes (see boxes) but their use has been - and in many instances still is - associated with the concept of eradication/elimination of pest populations from ecologically isolated regions (Hendrichs et al., 2005). This is perhaps logical and a direct result of the successful eradication of New World screwworm populations from the USA, Mexico and Central America (Meyer, 1994; Wyss, 2000; Vargas-Terán et al., 2005). Sterile insects have a unique biological advantage that matches them very well to the concept of eradication, i.e. their effectiveness increases as the pest population declines in numbers: their action is inversely dependent on the density of the target population (Dame, 1970). Once an isolated pest population begins to decline in numbers, following initial releases of a given number of sterile insects, continued releases at the same rate will result in increased ratios of sterile to wild males, which will not only accelerate that decline but will inevitably lead to elimination (Knipling, 1979). This is in contrast to many other pest control methods - such as insecticides and many biological control agents - where each treatment eliminates a constant proportion of the target population and which makes them much more effective at high pest population densities (Dame, 1970) than sterile insects. Consequently, the optimal efficiency in an area-wide integrated pest management programme is therefore obtained when control tactics are specifically chosen for their effectiveness at different pest population densities and used in sequence in order to maximise their effectiveness (Fig. 2).

Complete ecological isolation of a target population is not a requirement to achieve eradication providing the appropriate operational strategy is chosen, i.e. the rolling carpet principle (Hendrichs et al., 2005). In this strategy, the target area is divided into different treatment blocks, which are selected so as to minimise reinvasion pressure. Control is exercised along a unidirectional front and the four operational phases of area-wide integrated pest management (pre-intervention, population reduction, sterile male releases and maintenance/verification of low-prevalence/pest-free areas) are carried out simultaneously and in a phased manner. Therefore, once the programme has started, it cannot be interrupted until a pest-free area (in an eradication strategy) or the maintenance phase to sustain an area of low pest prevalence (in a suppression strategy) has been reached (Hendrichs et al., 2005). The New World screwworm programme in the Americas is an example of the rolling carpet principle. The programme started in the southern part of the USA in the 1950s and the control front advanced in the next 40 years through Mexico and the various countries of Central America, reaching Panama in the late 1990s (Wyss, 2000). Following the declaration of eradication in Panama, a permanent buffer zone of $30000 \mathrm{~km}^{2}$ was established in the Darien gap of Panama to protect the screwworm-free areas. Forty million sterile flies 
are released per week in the buffer zone to prevent reinvasion of the fly from South America (APHIS/USDA, 2001).

The intrinsic capability of sterile insects to actively search for and mate with the last individuals of a pest population and their increased effectiveness at low pest population densities makes them an ideal tool to deal with outbreaks of invasive pests (Vreysen et al., in preparation). Sterile insects were a component of programmes to eliminate biological incursions of the New World screwworm in Libya (Lindquist et al., 1992), the invasive Australian painted apple moth Teia anartoides Walker in New Zealand (Suckling et al., 2007), melon fly Bactrocera cucurbitae (Coquillett) in Okinawa, Japan, (Koyama et al., 2004), and cactus moth Cactoblastis cactorum (Berg) in Mexico (NAPPO, 2008). New pest incursions are characterised, initially at least, by low population densities, and adequate overflooding ratios of sterile to wild insects can often be easily obtained if adequate laboratory rearing protocols can be established. As new pest introductions usually have a patchy or fragmented distribution, the release of sterile insects is amongst the most effective ways of finding and eradicating these populations; much more effective than other control tactics (e.g. deployment of toxic baits) that depend on the judgement of entomologists or field technicians (Vreysen et al., in preparation).

Sustainability is a key concern for all pest control programmes. The state of eradication is, by definition, a sustainable end point as there are no individuals of the targeted pest species left in the ecologically isolated target area. The question is whether the sustainable end point can be sustained. In certain circumstances, this is not easy to achieve as areas can be re-infested either accidentally or deliberately and an extensive monitoring system is required to confirm that the area remains pest-free (Barclay et al., 2005). This is not only expensive, but maintaining support and funding over time can be difficult, leading to a reduction in vigilance and an increasing chance of re-infestation. However, programmes such as the elimination of the tsetse fly Glossina austeni Newstead from Unguja Island, Zanzibar (Vreysen et al., 2000) or the removal of the New World screwworm from Libya (Lindquist et al., 1992) have demonstrated that eradication programmes can be sustainable. Permanent vigilance is required to prevent re-introduction and sometimes, stringent measures such as the continuous release of sterile flies on the islands close to Taiwan in the Okinawa archipelago or in the Darien gap in Panama are needed to protect the cleared areas (Koyama et al., 2004; Hendrichs et al., 2005).

In the last decade, sterile insects have increasingly been considered as part of area-wide integrated pest management suppression programmes against certain strategic pest insects. This is due to the fact that the rearing and release of sterile insects such as the Mediterranean fruit fly Ceratitis capitata (Wiedemann) has become much more cost-effective, and the use of insecticides has become much more restricted and more complex due to intermingling of commercial production areas with human settlements, increased demand for organic food, and difficulties in establishing effective quarantine measures to maintain an area pest-free (Hendrichs et al., 2005). A suppression strategy requires significantly lower investment in mon- itoring and quarantine measures need not be so stringent as compared to those required for eradication. These trends have resulted in more frequent use of sterile insects for suppressing populations of the Mediterranean fruit fly as an alternative to the use of insecticides (Barnes et al., 2004). This strategy has mainly gained acceptance for use against crop pests, as a certain level of crop damage can be tolerated; something that is much more difficult with pests of veterinary or human health importance (Hendrichs et al., 2005). The various strategies are described in more detail in Section 3.6 and in Box 1.

\subsection{Rearing insects}

The ability to rear the target insect using an artificial diet was one of the essential factors that enabled the use of sterile insects for New World screwworm control (Brown, 1984; Marroquin, 1985). Rearing insects for sterile release requires firstly the development of an artificial diet followed by upscaling and automation of the processes to, in some cases, an industrial level (Parker, 2005). For example, the Mediterranean fruit fly mass-rearing facility in El Pino, Guatemala, currently produces 2000 million sterile male insects per week but has the capacity to produce 3500 million/week (Fig. 3, Tab. I) (Tween, 2002; IAEA, 2008).

As the scale of rearing increases, the selection pressure on the insect to adapt also increases and this can lead to behavioural changes in the colony that impact on the ability of the sterile insects to perform adequately in the field. The quality of insects for use in programmes has to be defined in terms of "fit for purpose". In the rearing facility, high productivity and survival are paramount, whereas in the field, the only quality aspects of relevance are the ability of the sterile males to find, mate with and effectively inseminate wild females (Lance et al., 2000; Vreysen, 2005). These differing quality requirements are not always readily attained, but the importance of the quality of the released insect in the field rather than performance in the rearing facility is receiving more and more attention (Simmons et al., 2010).

\subsection{Producing sterile males}

Successful use of sterile insects requires that the sterile males locate, mate with and effectively fertilise the wild females (Knipling, 1979). The basic reproductive biology of most insects would indicate that only males need to be released for the sterile insect technique to be effective (Franz, 2005). What, if any, is the role of the released sterile females in the field? At best they can be considered neutral but at worst they may provide an opportunity for assortative mating with the released sterile males and so divert the males from seeking out and mating with wild females (Rendón et al., 2000, 2004).

Mathematical modelling has indicated that in species where there is a male-choice mating system (such as the screwworm), asymmetric mating due to colonisation processes (sterile males mate at random with wild and sterile females, 


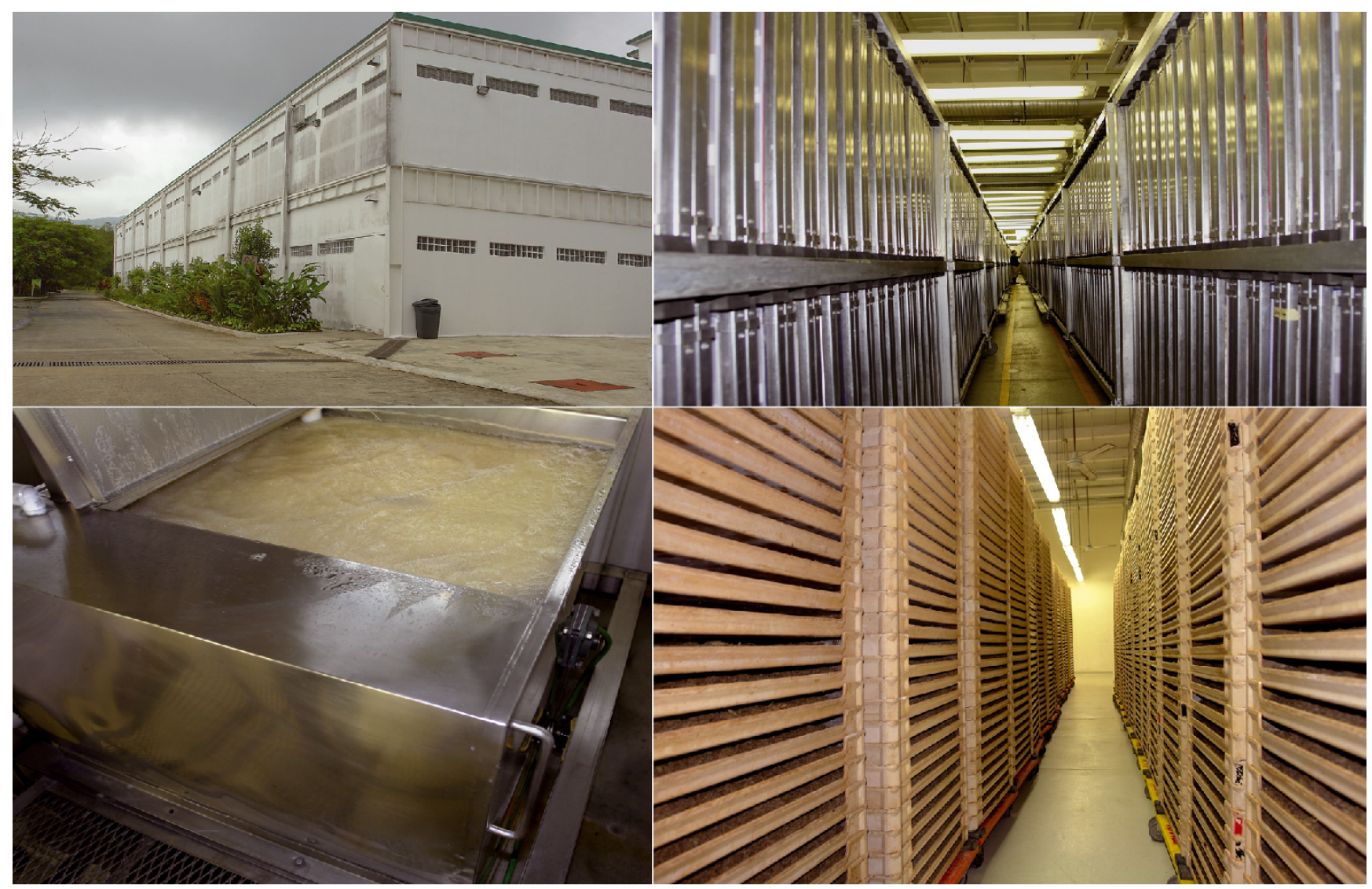

Figure 3. (Upper, left) the Mediterranean fruit fly mass-rearing facility in El Pino, Guatemala, (lower, left) heat treatment of eggs to remove the female sex - each water bath contains 390 million eggs, (upper, right) racks of cages with adult flies, and (lower, right) racks with larval rearing trays (photos courtesy of Gerald Franz, reproduced with permission).

whereas wild male screwworms mate preferably with wild females) requires a doubling of the amount of sterile insects released per unit surface area to get the same level of suppression as compared with a situation where there is random mating. The release of only sterile males of a species that has a femalechoice mating system - such as tropical fruit fly species - is more efficient in population suppression than the release of both sterile males and sterile females. In such species the number of multiple matings per male needs to be minimised because both sperm quality and quantity diminish with successive matings. In addition, sterile males distribute themselves more widely when sterile females are absent (Vreysen et al., 2006a).

Whatever the situation in the field, the production and release of sterile females incur an economic cost to the programme as they have to be reared, marked, irradiated and released along with the males. Rearing and releasing insects is a major cost factor and the removal of females would increase effectiveness (McInnis et al., 1994; Hendrichs et al., 1995; Rendón et al., 2004) and deliver significant economic benefits (LaChance, 1979). For human disease vectors such as mosquitoes where only the female is the obligatory blood feeder, the removal of females from the release insects is essential (Lance and McInnis, 2005).
Very few sex-linked differences in insects have been discovered thus far, which might facilitate large-scale separation of males and females. Consequently, New World screwworm (Baumhover, 1966) and Lepidoptera (Bloem et al., 2005) sterile insect technique programmes have been implemented by releasing both sexes. Discrete differences between the sexes can be produced if certain mutations (e.g. pupal colour, resistance to insecticides, sensitivity to temperature) are linked to either sex (Robinson, 2002). In the case of the Mediterranean fruit fly, a genetic sexing strain that carries two mutations (temperature-sensitive lethal (tsl) (Franz et al., 1994) and white pupae (wp) (Rössler, 1979)) is now routinely used in all sterile insect release programmes for this species, the global weekly production being 3500 million (Franz, 2005).

\subsection{Inducing sterility}

A major obstacle facing the entomologists who pioneered the use of sterile insects was that they did not know of any means to induce sexual sterility in insects. Although X-rays had been shown in the early part of the century to be able to sterilise insects (Runner, 1916) it was not until 1950 that, following communications between Müller and Knipling's 
Table I. Selected rearing facilities and production capacity of various fruit flies, screwworm flies and moths.

\begin{tabular}{|c|c|c|c|c|c|}
\hline Insect/s & Name & Country & City & Operated by & Capacity/week \\
\hline \multirow[t]{12}{*}{ Ceratitis capitata } & Infruitec Medfly Facilities & South Africa & Stellenbosch & Agricultural Research Council & 5 million \\
\hline & $\begin{array}{l}\text { USDA Pacific Basin Area Research } \\
\text { Center }\end{array}$ & United States of America & Honolulu & USDA/ARS & 5 million \\
\hline & Medfly facility & Tunisia & Tunis & $\begin{array}{l}\text { National Center of Nuclear Sciences } \\
\text { and Technologies (CNSTN) }\end{array}$ & 10 million \\
\hline & UOC-Fruit Flies & Greece & Heraklion, Crete & Biology Department & 10 million \\
\hline & Bio-Fly & Israel & Sde Eliyahu & Bio-Fly & 25 million \\
\hline & Centro Produccion Insectos Esteriles & Chile & ARICA & Servicio Agricola y Ganadero (SAG) & 30 million \\
\hline & Florida Department of Agriculture & United States of America & Gainesville & FDACS, DPI & 50 million \\
\hline & $\begin{array}{l}\text { Biofábrica do Programa Madeira-Med } \\
\text { Centro de Producción y Esterilización }\end{array}$ & Portugal & Camacha & Madeira Regional Governement & 50 million \\
\hline & Mosca de la Fruta La Molina - CPELM & Peru & Lima & Servicio Nacional de Sanidad Agraria & 160 million \\
\hline & Bioplanta KM8 & Argentina & Mendoza & ISCAMEN & 200 million \\
\hline & Planta Moscamed, Metapa & Mexico & Metapa de Dominguez & Senasica / USDA & 550 million \\
\hline & E1 Pino & Guatemala & Santa Rosa & USDA/MOSCAMED & 3000 million \\
\hline Bactrocera tryoni & Queensland fruit fly production facility & Australia & Camden & New South Wales Agriculture & 15 million \\
\hline Bactrocera philippinensis & Philippine Fruit Fly Mass Rearing Facility & Philippines & Quezon City & Philippine Nuclear Research Institute & 15 million \\
\hline Bactrocera dorsalis & $\begin{array}{l}\text { Irradiation Center for Agricultural } \\
\text { Development }\end{array}$ & Thailand & Bangkok & Department of Agricultural Extension & 30 million \\
\hline Anastrepah ludens & Mexican Fruit Fly Rearing Facility & United States of America & Edinburg & USDA APHIS PPQ & 160 million \\
\hline Bactrocera cucurbitae & $\begin{array}{l}\text { Okinawa Prefectural Agricultural } \\
\text { Experiment Station }\end{array}$ & Japan & Okinawa & Okinawa Prefectural Government & 200 million \\
\hline Anastrepha ludens, A. obliqua & MOSCAFRUT & Mexico & Chiapas & Mexico Government & 600 million \\
\hline Bactrocera oleae & Bio-Fly & Israel & Sde Eliyahu & Bio-Fly & 0.04 million \\
\hline Pectinophora gossypiella & Pink Bollworm Rearing Facility & United States of America & Phoenix & USDA-CDFA & 196 million \\
\hline Cydia pomonella & $\begin{array}{l}\text { Okanagan-Kootenay Sterile Insect Release } \\
\text { Comisión México Americana para la }\end{array}$ & Canada & Osoyoos & Regional Districts (local government) & 15 million \\
\hline Cochliomyia hominivorax & $\begin{array}{l}\text { Erradicación del Gusano Barrenador del } \\
\text { Ganado. }\end{array}$ & Mexico & Chiapas & USDA-SAGARPA & 500 million \\
\hline
\end{tabular}

group, the use of ionising radiation was considered as a potential technique for insect sterilisation (Bushland and Hopkins, 1951, 1953). Geneticists understood very well that ionising radiation induced sterility, i.e. dominant lethal mutations in germ cells of irradiated insects (Van Borstel, 1962). These mutations are caused by breakage of chromosomes in the germ cells and when sperm carrying these mutations fertilise eggs, the resulting embryo dies (LaChance et al., 1967). The word "sterility" suggests a single state or condition; however, ionising radiation induces levels of sterility, which are dependent on the dose of radiation used: the higher the dose, the higher the level of sterility (LaChance et al., 1967; Van der Vloedt et al., 1978; Vreysen, 1995; Vreysen et al., 1996). Ionising radiation not only induces dominant lethal mutations in the germ cells but also causes mutations in somatic cells, and in some species this impacts on the overall quality of the insect after radiation (Sakurai et al., 2000), expressed as the development of abnormalities, a reduction in lifespan, flight ability, mating propensity, etc. (Bakri et al., 2005a). In general, doses of ionising radiation have been used which lead to full sterility and this impacts negatively on insect quality, although recent publications (Toledo et al., 2004; Parker and Mehta, 2007) suggest that using a lower dose with less sterility but increased quality is more efficient at introducing sterility into the field population. Using a mathematical model, Klassen and Creech (1973) found that the rate of increase in a population to be suppressed determines the effectiveness of the combination of levels of male sterility and release ratios. When the rate of increase is low (e.g. five-fold), $90 \%$ male sterility can be effective at fairly low release ratios. By contrast, when the rate of increase is high (ten-fold or more) the level of sterility must be near $99 \%$ to induce a steep downward trend in the population (Klassen and Creech, 1973).

Sensitivity levels of insects to ionising radiation are affected by the level of oxygen present during irradiation (Economopoulos, 1977; Fisher, 1997). In an oxygen-reduced environment, the formation of free radicals during irradiation is reduced as compared with air, which lowers the damage induced by the ionising radiation. This entails the need for higher doses to obtain the same level of sterility (Bakri et al., 2005). This effect tends to be higher for somatic damage than for sterility and therefore, the use of hypoxia (a deficiency of oxygen reaching the tissues of the body) can be a strategy used to increase the competitiveness of an insect without compromising the level of sterility (Calkins and Parker, 2005; Lance and McInnis, 2005). Tephritid pupae are normally sealed in 
airtight plastic bags, with as little air as possible, and are left for about 1 hour before irradiation. During this period, the pupae exhaust most of the oxygen in the container. Saturating the atmosphere with helium or nitrogen before and during irradiation is another way of creating hypoxia (Ashraf et al., 1975; Hooper, 1989; Vreysen and Van der Vloedt, 1995).

Insect species vary in their sensitivity to the induction of sterility by ionising radiation, sometimes by an order of magnitude; for example, less than five Gy is required to sterilise Acrididae (Orthoptera) and Blaberidae (Dictyoptera), whereas doses above $200 \mathrm{~Gy}$ are in most cases required to sterilise pupae or adult Lepidoptera (Bakri et al., 2005a, b). However, in general insects can be divided into two groups depending on the type of chromosomes they possess. Some orders such as Lepidoptera and Hemiptera have holokinetic chromosomes (properties of the centromere are distributed over the entire chromosome (Kuznetsova and Chubareva, 1979)), which are very radiation-resistant and high doses of ionising radiation are required to induce sterility. However, the majority of insect Orders have monokinetic chromosomes and are considerably more radiosensitive. The high radiation doses needed to sterilise Lepidoptera reduced quality and hence their usefulness in field programmes. However, Proverbs (1962) discovered quite serendipitously that if codling moths Cydia pomonella (L.) were irradiated with a lower dose, the females were sterilised but not the males and the progeny from these males, both males and females, were fully sterile. This phenomenon has been termed $\mathrm{F}_{1}$ sterility or inherited sterility (North, 1967, 1975; LaChance, 1985).

Field releases of several lepidopteran pests such as the cabbage looper Trichoplusia ni (Hübner) (North and Holt, 1969), the corn earworm Helicoverpa zea (Boddie) (Carpenter and Gross, 1993), the gypsy moth Lymantra dispar (L.) (Mastro, 1993), the pink bollworm Pectinophora gossypiella (Saunders) (Staten, 1993; Walters, 2000) and the codling moth C. pomonella (Bloem et al., 2001) have demonstrated the efficacy of the inherited sterility.

\subsection{Sterile insect quality management}

The success of an area-wide integrated pest management programme that incorporates the release of sterile insects is dependent on many factors (Vreysen et al., 2007b), with adequate sterile insect quality being one of the most important. Released males have to intermingle rapidly with the wild population, locate the wild virgin females and be competitive with their wild counterparts in mating with wild females (Vreysen, 2005). The quality of the released insect can easily be impaired by aspects related to colonisation and massrearing processes (Parker, 2005), sterilisation with ionising radiation (Bakri et al., 2005a), and marking, handling, transport and release procedures (Calkins and Parker, 2005; Dowell et al., 2005). The quality of the reared insect has often mainly been assessed in the rearing facility, with little attention being given to its competitiveness once released in the target area (Vreysen, 2005). Quality management parameters in the mass-rearing facilities were more related to production pro- cesses (quantity) than to competitiveness (quality) in the field (Simmons et al., 2010). The sterile males' ability to seek out the native virgin females and to transfer the sterile sperm is a vital component of a sterile insect technique programme (Miyatake and Yamagishi, 1993). The monitoring in the field of the sterile males' sexual competitiveness, their mobility and dispersal capacity, and their dispersion (spatial distribution within the habitat) needs to be carried out rigorously, frequently and accurately to provide the programme managers with the data needed to make the necessary programme decisions (Vreysen, 2005).

\subsection{Monitoring insects}

As in most pest control programmes, the effectiveness of the applied control tactics is determined by monitoring the target insect population before, during and after a particular treatment. When sterile insects are used it is also necessary to monitor this component of the insect population in the field and to be able to differentiate released insects from wild insects. In some programmes it is also possible to monitor directly the induced sterility in wild females (Vreysen et al., 2000). Monitoring adult density or abundance is carried out using traps, which sample the insect population and provide some estimates of relative abundance. Trap design, placement, efficiency and insect activity all interact to provide on a regular basis some data on the numerical fluctuations of the wild population. This direct assessment can be complemented by indirect methods, e.g. fruit sampling to assess larval infestation levels for fruit flies and parasite levels in the case of insect vectors of disease (Vreysen, 2005).

Sterile insects are generally marked in the rearing facility with a fluorescent dust before release to be able to distinguish them from the wild insects when caught in traps but also to be able to monitor their survival and dispersal in the field (Parker, 2005). The ratio of wild males to sterile males is a key parameter in determining progress in the programme. An increasing ratio in favour of sterile males to wild males indicates that progress is being made, and if this can be combined with direct measurements of sterility levels in wild females then very important estimates of the competitiveness of the sterile males can be obtained (Vreysen, 2005).

A key question in eradication programmes is establishing absence of the pest: absence of evidence is not evidence of absence. This question is compounded by trap efficiency, which may very well change when field populations are driven to very low absolute densities. This problem can to a large extent be solved by knowing the generation time of the population in the field, having some estimates of trap efficiency and accepting some level of probability (Barclay et al., 2005). A recent mathematical model calculates, given a certain amount of traps in an area, an estimate of the efficiency of the used traps, the number of trapping days to catch an insect with a certain statistically acceptable level of probability (Barclay and Hargove, 2005). This user-friendly model (written in Excel) can be a great cost-saving factor, as it will not only give information of absence of the pest with a certain level of confidence, it 
will also provide guidance when to stop the releases (Clift and Meats, 2002, Vreysen, 2005).

In operational programmes that include the release of sterile males, the decision to stop releases is often influenced by political and financial motives. As an example, the dispersal of sterile New World screwworms in the Central American programme continued for 6-18 months after the last case had been detected (FAO, 1992; Wyss, 2000). In fruit fly programmes, it is standard procedure that releases continue for at least three fly generations after the last wild fly has been trapped (IAEA/FAO, 1997).

\subsection{Using sterile insects}

Although historically the use of sterile insects has been associated with the elimination of local pest populations, and although sterile insects always function in the field by introducing sterility into wild females, they can be deployed in several different ways depending on the ecological situation, the pest threat and the programme goals. Sterile insects have been used successfully in eradication, suppression, containment and prevention programmes (Hendrichs et al., 2005) (see boxes 1, 2, $3,4)$. These options illustrate the flexibility with which sterile insects can be used to protect agricultural commodities from pests, be they endemic or exotic.

\section{Box 1. Suppression}

The FAO (2005) defines suppression as the application of phytosanitary measures in an infested area to reduce pest populations. Using this strategy, sterile insects are deployed simply as a biological insecticide in order to maintain the pest population below an agreed and acceptable economic injury level. This strategy has the advantage of decreased pesticide use, lower investment needed for monitoring and no need for rigorous quarantine measures, but it requires pre-export treatment (as part of a systems approach to develop Areas of Low Pest Prevalence), active participation of the growers, and the control effort has to be permanent (Hendrichs et al., 2005). This strategy has been applied successfully against the codling moth Cydia pomonella (L.) (Canada), the Mediterranean fruit fly Ceratitis capitata (Wiedemann) (Israel/Jordan, South Africa, Madeira, Spain and Tunisia), the oriental fruit fly Bactrocera dorsalis Hendel (Thailand), and the false codling moth Thaumatotibia leucotreta (Meyrick) (South Africa).

\section{Box 2. Eradication}

Eradication is defined as the application of phytosanitary measures to eliminate a pest from an area (FAO, 2005). This clearly implies the elimination of a local population, contrary to the definition used by the World Health Organization (WHO) where the term is restricted to global extinction (e.g. smallpox). The control efforts for the local eradication of a pest insect population are limited in time and cost, will eliminate all insecticide use in the target area eventually, and provide access to specific lucrative pest-free export markets.
The rigorous quarantine setup needed to maintain the area pest-free is costly, but this also benefits quarantine procedures against other pest insects. An eradication strategy usually requires a high, but short-term investment, and longterm good monitoring networks (Hendrichs et al., 2005).

\section{Box 3. Containment}

Containment programmes are adopted in and around an infested area to prevent spread of the pest (FAO, 2005). Classical examples are (1) the containment programme of the pink bollworm Pectinophora gossypiella (Saunders) in the San Joaquin Valley, where sterile insect releases have, since 1968, prevented the establishment of the pink bollworm in the valley, protecting a cotton crop with an annual value of USD 1000 million (Bloem et al., 2005), and (2) the containment programme of the Mediterranean fruit fly Ceratitis capitata (Wiedemann) on the Mexico-Guatemala border, that has protected the horticultural industry in Mexico and the USA since 1983. It is estimated that for every dollar invested in this programme, there has been a return of USD 167 in terms of crop revenue and savings in control costs (Enkerlin, 2005).

\section{Box 4. Prevention}

Prevention is defined as the application of phytosanitary measures in and around a pest-free area to avoid the introduction of a pest. This strategy is the most desirable in terms of cost as it is always cheaper to prevent outbreaks than control them, as is exemplified by the preventive sterile release programme in California. Periodic outbreaks of the Mediterranean fruit fly Ceratitis capitata (Wiedemann) in California were previously controlled by unpopular aerial applications of Malathion. Outbreaks in 1980 and 1982 required more than USD 100 million to bring the situation under control. In 1994, a preventive release programme was started which releases 400 million sterile male fruit flies per week over the 2500-square-mile target area. The programme costs about USD 15 million/year, which compares favourably with the cost of USD 30 million that was spent annually to control the outbreaks (Vreysen et al., 2006b).

\section{IONISING RADIATION AND NATURAL ENEMIES}

During the past 120 years, more than 2000 species of exotic arthropods have been introduced on more than $5000 \mathrm{oc}-$ casions into 196 countries for the control of arthropod pests. Many new exotic pests have established themselves in Europe, temporarily or permanently, as a result of increased acreage of protected grown crops. Biological control by augmentation or inundation is now a major component of pest control in protected crops in Europe (Loomans, 2006). The number of exotic natural enemies introduced and released has increased the last few decades, with about 90 species of natural enemies currently used and commercialised around Europe (EPPO, 2002). The increase in natural enemies shipped and released 
to control native and exotic pests may result in an increase in risks imposed on the environment, which has been the topic of several recent publications (e.g. Bigler et al., 2006). However, when appropriately applied, natural enemies are one of the most promising, environmentally-sound and effective tools for sustainable control of arthropod pests of agriculture, and biological control has been an accepted method of pest management for over 120 years in agriculture, forestry and rangeland areas and for medical and veterinary pests (van Lenteren et al., 2006; van Driesche et al., 2008).

In classical or inoculative biological control, nonindigenous biological control agents, usually selected from the suite of parasitoids, predators and diseases that co-evolved with the pest are introduced into the target area. One of the key concerns of this approach is the host specificity and host range of the natural enemies following release. There is always the possibility that introduced biological control agents "jump hosts" (Follet and Duan, 2000; Wajnberg et al., 2001), leading to criticisms (Hamilton, 2000; Louda et al., 2003) and ever more stringent environmental risk assessment protocols (van Lenteren et al., 2006). In cases where doubts remain about very promising natural enemies of weeds or insect pests, they can be radiation-sterilised before release to enable a more definite assessment to be made under natural conditions of host specificity without any risk of permanent establishment (Hendrichs et al., 2009).

Ionising radiation has other roles to play in the area of augmentative or inundative biological control where natural enemies are mass-reared and released in very large numbers, often several times each season. Augmentative biological control faces challenges including the cost of production, quality control and quality assurance, shipping and regulation, and radiation can facilitate some of these issues (Hendrichs et al., 2009).

\subsection{Ionising radiation for improved rearing}

Ionising radiation can sometimes suppress the immune response of the hosts, and thereby make older larval instars suitable for parasitoid development. A radiation-impaired immune system would also allow the production of natural enemies on easier to rear factitious or non-habitual hosts (Genchev et al., 2007) or on those that are more economical to massrear (Hamed et al., 2009). Certain complex, difficult to study physiological processes in the host (e.g. defence mechanisms, hormone metabolism), which are not well understood in relation to improved rearing efficiency, can be selectively modified by ionising radiation, thereby facilitating the study of particular host-parasitoid interactions. Ionising radiation can arrest development of certain species of hosts and prey, thereby increasing their shelf life and allowing for storage and stockpiling (Celmer-Warda, 2004; Seth et al., 2009; Zapater et al., 2009). It can also delay normal insect development and thus may extend the time window for host parasitisation or modify the internal host environment to the benefit of the natural enemy (Cancino et al., 2009; Fatima et al., 2009; Hamed et al., 2009; Zapater et al., 2009). In most insect mass-rearing facilities, excess production of particular insect life stages or batches of sub-standard insects are normally discarded, which requires an investment for their disposal. These excess products may be processed instead (Nakashima et al., 1996) or irradiated, if still alive, to support the production of natural enemies (Cancino et al., 2009).

\subsection{Ionising radiation to facilitate handling, shipment, trade and release}

During mass-production of natural enemies, a certain proportion of the hosts or prey insects may not be parasitised or eaten and will therefore develop normally, which requires additional handling steps to remove these fertile individuals from the rearing process. This decreases efficiency in large-scale mass-rearing, and can be avoided by irradiating the hosts and prey to inhibit further development and prevent the need for costly separation procedures (Cancino et al., 2009).

\subsection{Integrating the sterile insect technique (SIT) or $\mathbf{F}_{1}$ sterility and natural enemies}

The release of sterile or semi-sterile insects together with natural enemies has been known to have synergistic effects for population suppression when applied simultaneously (Knipling, 1992; Wong et al., 1992; Bloem et al., 1998). This synergy results from the sterile insects curtailing reproduction of the adult stage of the target pest, while natural enemies destroy one or more of its immature stages, including reproducing on the $F_{1}$ offspring in $F_{1}$ sterility releases. However, successful integration of these two control tactics is only possible if the natural enemies do not negatively impact the irradiated insects and their progeny more than the wild population, and if $F_{1}$ sterility does not negatively impact the efficacy and reproduction of natural enemies. The possibility of parasitisation on progeny from irradiated males and untreated females was demonstrated in studies in the laboratory, field cages and in the wild with irradiated and untreated (1) male Spodoptera exigua (Hubner) as a host for the braconid larval parasitoid Cotesia marginiventris (Cresson) (Carpenter et al., 1996), (2) male $H$. zea as a host for the tachinid Archytas marmoratus (Townsend) (Mannion et al., 1994), and (3) C. pomonella as a host for the egg parasitoids Trichrogramma cacoeciae (Marchal) and Triochogramma nerudai (Pintureau and Gerding) (Botto and Glass, 2010).

\section{PROTECTING THE ENVIRONMENT}

The presence of sterile insects in the environment presents little or no threat (Nagel and Peveling, 2005). They are biodegradable, they act in a species-specific manner and they do not persist when releases are terminated. Consequently, the sterile insect technique is considered to be amongst the most environmentally-friendly insect pest control tactics. However, prior to arriving in the environment they have to be reared, 


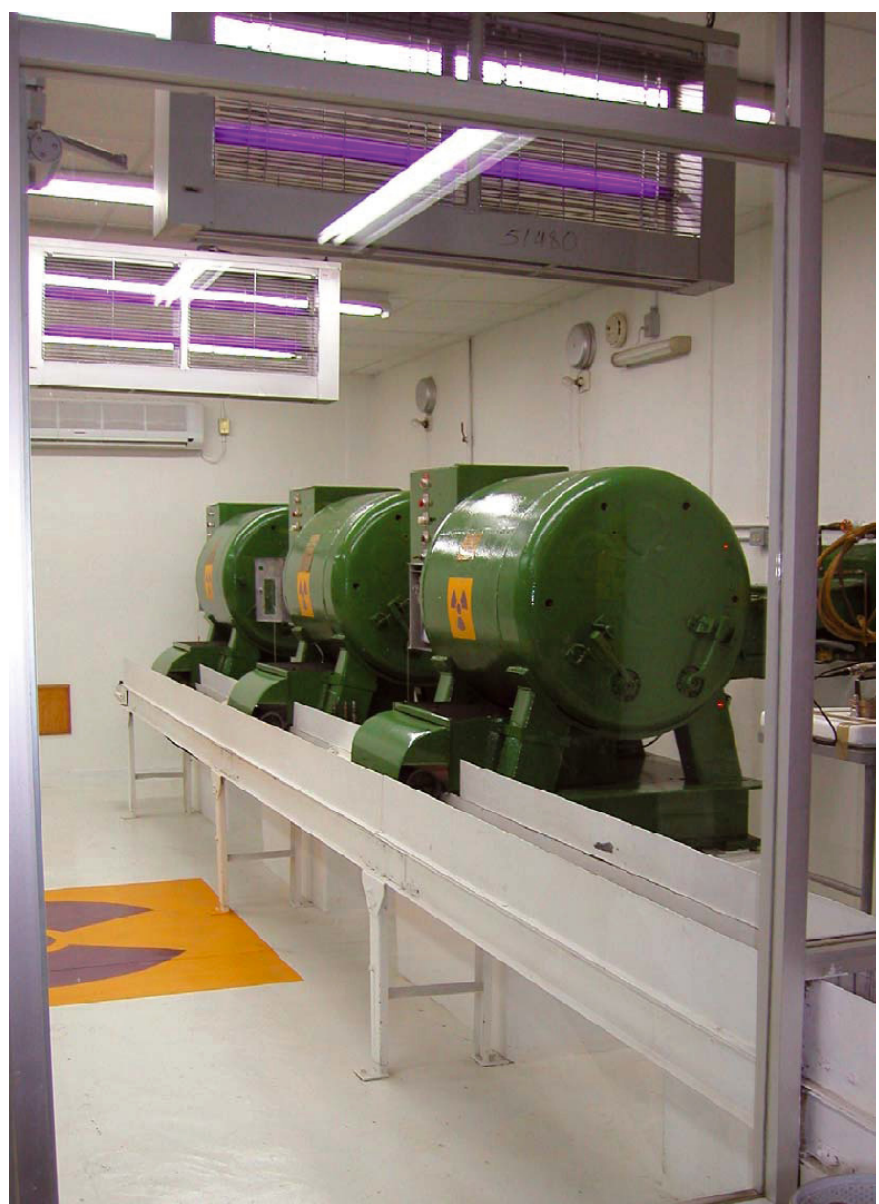

Figure 4. The three ${ }^{137} \mathrm{Ce}$ Husman gamma irradiators at the New World screwworm mass-rearing facility in Tuxtla Gutièrrez in Chiapas, Mexico.

sterilised and released, all processes that impact the environment in some way, but probably in a similar way to the manufacture of other products for pest control. Large rearing facilities have to be built and they produce many tons of spent diet a day that has to be treated before being used for other purposes, and waste water management is a priority (IAEA, 2008). Biosecurity is an issue where facilities find themselves in eradicated areas through the course of a successful programme, e.g. the New World screwworm mass-rearing facility in Tuxtla Gutièrrez in Chiapas, Mexico (Wyss, 2000). For insect sterilisation, conventional self-shielded irradiators (Fig. 4) are used and the dose received by the irradiated insects is quantified by standard dosimetry (Parker and Mehta, 2007). The transport and importation of this type of gamma cell is governed by international safety procedures and standards and its operation is under strict control by competent national authorities to ensure its safety and security. Releasing insects in large programmes is frequently carried out by aircraft, which again is well regulated and poses no environmental concerns. Many of these same concerns also apply to the mass production of natural enemies, although biosecurity is probably less of a concern, except where pest species are used as hosts.

\section{ENHANCING SUSTAINABLE AGRICULTURE}

Area-wide integrated pest management programmes using sterile insects and natural enemies are complex and management-intensive, and there is no guarantee of success (see Vreysen et al., 2007b). It is beyond doubt that the use of these biological control agents in area-wide integrated pest management programmes has resulted in high benefit-cost ratios (Mumford, 2005) and these programmes have played and continue to play a significant role in reducing the total amount of insecticides applied (Vreysen et al., 2006b).

The highest benefit-cost ratios are usually obtained in programmes that are operated to protect a high-value crop and its export market (e.g. export of fruits, vegetables, etc. to large markets of industrialised nations such as the EU, USA and Canada) or to protect an extensive livestock industry (e.g. cattle industry in southern USA). In those cases, it has been relatively easy to convince federal or regional governments, and farmers' associations to invest the necessary funds to operate these programmes as the benefits are very obvious. In the case of protecting subsistence farming in sub-Saharan Africa, it becomes much more difficult to find the funding for these programmes as there are no big industries or export markets to protect: what is protected are individual animals or crops, herds, and the livelihood of farmers. However, the very impressive programme that controlled the cassava mealy bug in large areas of Africa using a natural enemy showed the potential, even under very difficult conditions (Herren and Neuenschwander, 1991).

Insect pests cause both direct and some indirect losses, which translate into direct and indirect benefits when the pest is managed in an appropriate way. Direct benefits are fairly easy to account for and are measured in terms of increase in yield (e.g. number of fruits produced, milk and meat yield, reduced mortality, reduced abortions, increased longevity, etc.), improved quality of the produced commodities, and reduced production costs through more effective management of the pest (Enkerlin, 2005). Indirect benefits are more difficult to incorporate in the benefit-cost equations and can include an increase in export volumes, increase in yield through reduced secondary pest outbreaks, savings in medical costs as a result of exposure to insecticides, reduced legal costs arising from damage to private and public property due to insecticide misuse, increased human health due to reduced insecticide residues in food commodities, new jobs created, better human nutrition, etc. (Enkerlin, 2005).

The following examples provide ample evidence of the significant contribution area-wide integrated pest management has made to sustainable agriculture.

\subsection{New World screwworm in the Americas}

Using an area-wide integrated pest management approach and sterile insects, the New World screwworm was eradicated from the USA during the period 1957-1966 (Knipling, 1960) although there were several re-introductions, with the last six cases in Texas in 1982 (Jim Novy, unpublished report to the 
FAO), Mexico was declared free of the New World screwworm in 1991, and the remainder of Central America was declared New World screwworm-free over a period of 12 years (from 1988 to 2000) (Vargas-Terán, 2005). The annual direct producers' benefits from the eradication of screwworm were estimated at USD 896 million for the USA, USD 328 million for Mexico and USD 87.8 million for Central America (Wyss, 2000). The benefits were derived from decreases in death losses, decreases in veterinary services, veterinary medicines, insecticides and inspections, and increases in meat and milk production. These effects have, however, an indirect impact on the general economy of each country and the multiplier effect is estimated at 3 (Wyss, 2000). Since the first sterile New World screwworms were released on Curaçao, an estimated USD 1000 million has been spent on the eradication campaign over 50 years. The annual direct benefits that accrue every year from this programme are therefore equal to or more than the total project cost over five decades. Whereas in 1934 screwworm infestations killed 1.3 million cattle in the south-eastern USA (Dove, 1937) and in 1935, in Texas alone, 230000 screwworm cases were detected (FAO, 1992), the screwworm saga has been erased from the memories of today's US livestock owners.

\subsection{Chile's National Fruit Fly programme}

Export of fruit and vegetables is an important component of the economy of Chile. Chile's most important trading partners are the USA and Japan, who impose stringent import conditions: the produce needs to be produced in a fruit flyfree area. Only the northern province of Arica was infested with the Mediterranean fruit fly, and following the use of bait sprays and sterile insects, Chile was declared a fruit fly-free country in 1995 (MAG/SAG, 1995). Since then, Chile's National Fruit Fly programme has been able to prevent the introduction and the establishment of fruit flies of economic importance. The programme uses two main strategic activities, i.e. (1) a preventive programme based on effective quarantine measures and an extensive trapping network, and (2) in collaboration with Peru and Argentina, a containment programme in Arica province using twice-weekly releases of 50 million sterile males (Gonzalez and Troncoso, 2007). Since Chile was declared a fruit fly-free country, annual fruit exports have grown to two million tonnes of mainly grapes, apples, stone fruits, kiwis and avocados with an estimated value of USD 1600 million. The annual export of fruit from the area that could harbour the Mediterranean fruit fly amounts to USD 250 million. However, the Government of Chile spends only USD 4 million each year to keep the country free of fruit flies (Enkerlin, 2005).

\subsection{Melon fly in Okinawa}

The melon fly B. cucurbitae is one of the most destructive pests of cucurbit crops. This pest invaded the Okinawa Islands of Japan from 1910 to 1970, thereby preventing the export of 40 important vegetables and fruits to fruit fly-free areas, such as the main islands of Japan. In 1979, an area-wide integrated pest management programme was initiated that integrated the use of the male annihilation technique with the release of sterile insects. All islands were declared free of melon fly in 1993 and this status is maintained through a continuous detection programme, rigorous quarantine measures and preventive releases on the island closest to Taiwan that is still infested. As a result of the programme, between 1990 and 2000, melon production increased 2.3 times (from 2720 to 6220 tonnes) and the production of mango 4.6 times (from 278 to 1290 tonnes), or an equivalent of USD 335 million. A total of USD 172 million was invested for the main eradication campaign between 1982 and 1991. However, six years after achieving eradication, the break-even point had been reached, and between 1997 and 2000, revenues from the sale of commodities to mainland Japan totalled USD 169 million. For the same period, only USD 31 million was required to keep the islands free of new invasions (Enkerlin, 2005).

\subsection{Cassava mealy bug in Africa}

Although the theoretical basis for the combined use of sterile insects and natural enemies was already established by Knipling (1992) and numerous laboratory, semi-field and field experiments have indicated the synergistic benefits (e.g. Wong et al., 1992; Bloem et al., 1998), the principle has not found a practical follow-up "as yet" on a large operational scale. This is remarkable as both sterile insects (Dyck et al., 2005) and natural enemies (Hokkanen and Lynch, 1996) have been used successfully to tackle major insect pests. One of the most impressive classical biological control programmes was undoubtedly the one directed against the cassava mealy bug Phenacoccus manhoti Mat.-Ferr. (Homoptera: Pseudococcidae) in Africa. The mealy bug was first detected in Zaire and Congo in the early 1970s (Herren and Neuenschwander, 1991) and spread the following 10 years over the entire cassava belt of Africa, with the exception of Madagascar, causing root yield losses of up to $84 \%$ (Herren et al., 1987). A parasitoid wasp Apoanagyrus (Epidinocarsis) lopesi (DeSantis), originating from the mealy bug's native home Paraguay, was selected as the prime candidate for a release programme. Aerial releases of the parasitoid wasp were initiated in 1981 and by 1991 the biological control agent had been spread to 26 African countries covering 3 million $\mathrm{km}^{2}$ (Neuenschwander, 1993), bringing the pest under control in $95 \%$ of all the cassava fields (Herren and Neuenschwander, 1991). An economic analysis that tabulated the benefits and costs over a period of 40 years (1974-2013) indicated a benefit-cost ratio of the programme of 200 when cassava was listed at world market prices and of about 370-740 when inter-African prices were considered (Zeddies et al., 2001).

\subsection{The private sector enters the fruit fly industry in Israel}

Suppression of the Mediterranean fruit fly in the Arava/Araba Valley (Israel/Jordan) was initiated in 1998. 
Initially, the programme imported 15 million sterile male pupae weekly from the El Pino Moscamed mass-rearing facility in Guatemala. After September 11, 2001, airfreight regulations changed drastically, which significantly increased the duration of the pupal shipments, with increased pupal mortality and a general decline in fly quality as a consequence. As a result, Bio-Bee, an Israeli company that mass-produces and markets biological control agents and bumblebees, conducted in 2003 a study to assess the economic feasibility of establishing a rearing facility. A new company named Bio-Fly was established in the Kibbutz Sde Eliyahu and the rearing facility was inaugurated in March 2005. The facility currently produces 20-25 million sterile male flies every week (Franz, 2005), although its maximum production capacity is estimated at 50 million sterile males per week using the existing infrastructure. Bio-Fly delivers sterile male flies to projects in the Golan Heights (800 ha. of deciduous fruits), the Sea of Galilee ( 800 ha. of mangos and citrus), to Beit-Shean (300 ha. of citrus), to Lachish Tali grapes (600 ha. of grapes), to the West Negev (200 ha. of citrus), and to the Arava-Araba valley (4000 ha. of commercial plots and backyards) (Dael Levy, General Manager, Bio-Fly, pers. commun.). Whereas before 1998 the Arava Valley was not able to export any agricultural commodity to the USA, export of bell peppers and tomatoes to the USA had increased to USD 500000 in 1999 and to USD 50 million in 2003-2004.

\subsection{Codling moth in Canada}

The codling moth $C$. pomonella is the most important pest of pears and apples in British Columbia, Canada (Bloem and Bloem, 2000). A pilot programme, conducted from 1976 to 1978 in the Similkameen Valley, BC, demonstrated that a combination of suppressive action with chemicals and the release of sterile moths could eliminate codling moth (Proverbs et al., 1982). Operational activities were initiated in the Okanagan Valley in 1995 and since then, the apparent density of the wild codling moth population in the first intervention zone (as revealed through adult moth catches in pheromone traps) was reduced from an average of 2.5-13 moths/trap/week to an average of 0.08 moths/trap/week in 2000 (Bloem et al., 2005). In the first zone, the proportion of orchards with no detectable codling moth damage increased from $42 \%$ in 1995 to $91 \%$ in 2000 , while the amount of organophosphate insecticides purchased decreased from $18903 \mathrm{~kg}$ in 1991 to $3403 \mathrm{~kg}$ in 2001 (Bloem et al., 2005).

\section{THE FUTURE}

There are several areas where the sterile insect technique could be improved and made more efficient. The quality of released insects and hence, their ability to locate virgin females and transfer the sperm is of prime importance for success of the technique. The use of field-based protocols that rigorously assess the impact of changes in the rearing and handling on the quality of the insect should be standard procedure (Vreysen,
2005). One can compensate for low insect quality to a certain extent by releasing a larger number of insects, but there are limits to this both economically and biologically, i.e. below a certain quality factor, further increases will simply not be effective. Genetic studies need to shed light on the amount of insects needed to initiate insect colonies with adequate genetic variability and how this variability can be maintained throughout the rearing process. Insects adapt rapidly to artificial conditions and successful colonisation results in the selection for adapted genotypes that can negatively impact on their competitiveness. Strain replacement at regular intervals has been used in the past to compensate for this but is logistically very demanding. The filter rearing system concept, where a mother colony is maintained under relaxed, more natural conditions, has shown great potential for some fruit fly species. The mother colony is checked at every generation and unwanted individuals are removed. Eggs from the mother colony are used to produce a large colony from which insects are taken for release following 3-4 generations of amplification. This strategy not only reduced selection pressure but can also maintain the integrity of genetic sexing strains (Fisher and Cáceres, 2000; Cáceres et al., 2004). Other areas that have great potential to increase the efficiency of the sterile insect technique are improvement of artificial diets through the inclusion of micro-organisms that contribute nutrients, the addition of hormonal, nutritional, semio-chemical supplements to enhance sterile male performance, increased fitness through hybrid strains, increased shelf life of certain life stages that would make sterile insects available in large numbers when needed in the season, improved shipping procedures to reduce negative effects of transport, reducing the negative impact of ionising radiation, improved release procedures, monitoring techniques, etc. Modern biotechnology will most likely also contribute to increased efficiency and programmes could benefit from transgenic techniques in terms of insect marking, genetic sexing, molecular sterilisation and disease refractoriness (Robinson and Hendrichs, 2005).

\section{CONCLUSIONS}

The suppression, containment, prevention or eradication of pest insects will in most cases result in more sustainable pest control when the various control tactics are applied on an areawide basis, i.e. against an entire pest population within a delimited geographical area. Both sterile insects and natural enemies have been used very successfully in the past to control important insect pests. Although both control tactics are complementary and in some circumstances even synergistic, their combined use has not yet found a practical follow-up. Ionising radiation is not only a very suitable, effective and safe way to produce sterile insects, it can also be used in many ways to increase the usefulness of natural enemies for insect control. Both natural enemies and sterile insects, when appropriately used, have minimal negative effects on the environment. There are numerous examples of past and ongoing operational programmes that have successfully deployed sterile insects or natural enemies that have resulted in enormous economic benefits 
and in many cases have opened up very lucrative export markets of agricultural commodities. There is great potential to use these control tactics and strategic approaches against major insect pests in the future and the potential for economic growth and enhanced agriculture could motivate farmers to apply these approaches more in an area-wide context.

\section{REFERENCES}

(APHIS/USDA) Animal and Plant Health Inspection Service/United States Department of Agriculture. (2001) Screwworm programme review, Final Report.

Ashraf M., Chatha N., Ohinata K., Harris E.J. (1975) Melon flies: dosageresponse and sexual competitiveness after treatment with gamma irradiation in a nitrogen atmosphere, J. Econ. Entomol. 68, 838840.

Bakri A., Metha K., Lance D.R. (2005a) Sterilizing insects with ionizing radiation, in: Dyck V.A., Hendrichs J., Robinson A.S. (Eds.), Sterile insect technique. Principles and practice in area-wide integrated pest management, Springer, Dordrecht, The Netherlands, pp. 233-268.

Bakri A., Heather J., Hendrichs J., Ferris I. (2005b) Fifty years of radiation biology in entomology: lessons learned from IDIDAS, Ann. Entomol. Soc. Am. 98, 1-12.

Barclay H.J., Hargrove J.W. (2005) Probability models to facilitate a declaration of pest-free status, with special reference to tsetse (Diptera: Glossinidae), Bull. Entomol. Res. 95, 1-11.

Barclay H.J., Hargrove J.W., Clift A., Meats A. (2005) Procedures for declaring pest free status, in: Dyck V.A., Hendrichs J., Robinson A.S. (Eds.), Sterile insect technique. Principles and practice in area-wide integrated pest management, Springer, Dordrecht, The Netherlands, pp. 363-386.

Barnes B.N., Eyles D.K., Franz G. (2004) South Africa's fruit fly SIT project - the Hex River Valley pilot project and beyond, in: Barnes B.N. (Ed.), Proceedings of the 6th International Symposium on Fruit Flies of Economic Importance, 6-10 May 2002, Stellenbosch, South Africa, Isteg Scientific Publications, Irene, South Africa, pp. 131-141.

Baumhover A.H. (1966) Eradication of the screwworm fly. An agent of myiasis, J. Am. Med. Assoc. 196, 240-248.

Baumhover A.H., Graham A.J., Bitter B.A., Hopkins D.E., New W.D., Dudley F.H., Bushland R.C. (1955) Screwworm control through release of sterilized flies, J. Econ. Entomol. 48, 462-466.

Bigler F., Babendreier D., Kuhlmann U. (2006) Environmental risks of invertebrate biological control agents: methods and risk assessment, CABI publishing, Wallingford, UK.

Bloem K.A., Bloem S. (2000) SIT for codling moth eradication in British Columbia, Canada, in: Tan K.H. (Ed.), Area-wide Control of Fruit Flies and Other Insect Pests, Proceedings of an International Conference on Area-wide Control of Insect Pests and the 5th International Symposium on Fruit Flies of Economic Importance, 28 May-5 June 1998, Penang, Malaysia, Penerbit Universiti Sains, Malaysia, pp. 207-214.

Bloem K.A., Bloem S., Carpenter J.E. (2005) Impact of moth suppression/eradication programmes using the sterile insect technique or inherited sterility, in: Dyck V.A., Hendrichs J., Robinson A.S (Eds.), Sterile insect technique. Principles and practice in area-wide integrated pest management, Springer, Dordrecht, The Netherlands, pp. $677-700$.

Bloem S., Bloem K.A., Carpenter J.E., Calkins C.O. (2001) Seasonlong releases of partially sterile males for control of codling moth Cydia pomonella (Lepidoptera: Tortricidae), in Washington apples, Environ. Entomol. 30, 763-769.
Bloem S., Bloem K., Knight A.L. (1998) Oviposition by sterile codling moths, Cydia pomonella (Lepidoptera: Tortricidae) and control of wild populations with combined releases of sterile moths and egg parasitoids, J. Entomol. Soc. Brit. Columbia 95, 99-109.

Botto E., Glaz P. (2010) Potential for controlling codling moth Cydia pomonella (Linnaeus) (Lepidoptera: Tortricidae) in Argentina using the sterile insect technique and egg parasitoids, J. Appl. Entomol. $134,251-260$

Brown H.E. (1984) Mass production of screwworm flies, Cochliomyia hominivorax, in: King E.G., Leppla N. (Eds.), Advances and challenges in insect rearing, USDA-ARS, New Orleans, USA, pp. 193 199.

Bushland R.C., Hopkins D.E. (1951) Experiments with screwworm flies sterilized by X-rays, J. Econ. Entomol. 44, 725-731.

Bushland R.C., Hopkins D.E. (1953) Sterilization of screwworm flies with X-rays and gamma rays, J. Econ. Entomol. 46, 648-656.

Cáceres C., Cayol J.P., Enkerlin W., Franz G., Hendrichs J., Robinson A.S. (2004) Comparison of Mediterranean fruit fly (Ceratitis capitata) (Diptera: Tephritidae) bisexual and genetic sexing strains: development, evaluation and economics, in: Barnes B.N. (Ed.), Proceedings of the 6th International Symposium on Fruit Flies of Economic Importance, Isteg Scientific Publications, Irene, South Africa, pp. 367-381.

Calkins C.O., Parker A.G. (2005) Sterile insect quality, in: Dyck V.A., Hendrichs J., Robinson A.S. (Eds.), Sterile insect technique. Principles and practice in area-wide integrated pest management, Springer, Dordrecht, The Netherlands, pp. 269-296.

Cancino J., Ruíz L., López P., Sivinski J. (2009) The suitability of Anastrepha spp. and Ceratitis capitata (Diptera: Tephritidae) larvae as hosts of Diachasmimorpha longicaudata and Diachasmimorpha tryoni (Hymenoptera: Braconidae): Effects of host age and radiation dose and implications for quality control in mass rearing, Bio. Sci. Tech. 19, S1, 81-94.

Cardé R.T., Minks A.K. (1995) Control of moth pests by mating disruption: successes and constraints, Annu. Rev. Entomol. 40, 559-585.

Carpenter J.E., Gross H.R. (1993) Suppression of feral Helicoverpa zea (Lepidoptera: Noctuidae) populations following infusion of inherited sterility from released substerile males, Environ. Entomol. 22, 1084-1091.

Carpenter J.E., Bloem S., Marec F. (2005) Inherited sterility in insects, in: Dyck V.A., Hendrichs J., Robinson A.S. (Eds.), Sterile insect technique. Principles and practice in area-wide integrated pest management. Springer, Dordrecht, The Netherlands, pp. 115-146.

Carpenter J.E., Hidryani E., Sheehan W. (1996) Compatibility of $F_{1}$ sterility and a parasitoid, Cotesia marginiventris (Hymenoptera: Braconidae), for managing Spodoptera exigua (Lepidoptera: Noctuidae): acceptability and suitability of host, Fla. Entomol. 79, 289-295.

Celmer-Warda K. (2004) Preliminary studies on suitability and acceptability of irradiated host-larvae (Plodia interpunctuella) by larval parasitoids Venturia canescens (Gravenhorst), Ann. Warshaw Agr. Univ-SGGW, Horticulture, Landscape Architecture 25, 67-73.

Clift A., Meats A. (2002) When does zero catch in a male lure mean no tephritid flies in the area? in: Barnes B.N. (Ed.), Proceedings of the 6th International Symposium on Fruit Flies of Economic Importance, 6-10 May 2002, Stellenbosch, South Africa, Isteg Scientific Publications, Irene, South Africa, pp. 183-188.

Courschee R.J. (1960) Some aspects of the application of insecticides, Annu. Rev. Entomol. 5, 327-352.

Dame D.A. (1970) Control by sterilization of Glossina, in: Mulligan H.W. (Ed.), The African trypanosomiasis, Allen and Unwin Ltd, London, UK, pp. 533-542.

Dove W.E. (1937) Myiasis of man, J. Econ. Entomol. 30, 29-39. 
Dowell R.V., Worley J., Gomes P.J. (2005) Sterile insect supply, emergence and release, in: Dyck V.A., Hendrichs J., Robinson A.S. (Eds.), Sterile insect technique. Principles and practice in area-wide integrated pest management, Springer, Dordrecht, The Netherlands, pp. 297-324.

Dyck V.A., Hendrichs J., Robinson A.S. (2005) Sterile insect technique. Principles and practice in area-wide integrated pest management, Springer, Dordrecht, The Netherlands.

Economopoulos A.P. (1977) Gamma-ray sterilization of Dacus oleae (Gmelin). Effect of nitrogen on the competitiveness of irradiated males, Z. Ang. Entomol. 83, 86-95.

Enkerlin W.R. (2005) Impact of fruit fly control programmes using the sterile insect technique, in: Dyck V.A., Hendrichs J., Robinson A.S. (Eds.), Sterile insect technique. Principles and practice in area-wide integrated pest management, Springer, Dordrecht, The Netherlands, pp. 651-676.

EPPO European and Mediterranean Plant Protection Organization (EPPO) (2000) Safe use of biological control: import and release of exotic biological control agents, EPPO Standard PM6/2(1), http:// www.eppo.org.

Fatima B., Ahmad N., Memon R.M., Bux M., Ahmad Q. (2009) Enhancing biological control of sugarcane shoot borer, Chilo infuscatellus (Lepidoptera: Pyralidae), through use of radiation to improve laboratory rearing and field augmentation of egg and larval parasitoids, Bio. Sci. Tech. 19, S1, 277-290.

Food and Agriculture Organization of the United Nations (FAO) (1992) The New World screwworm eradication programme, North Africa (1988-1992), FAO, Rome, Italy.

Food and Agriculture Organization of the United Nations (FAO) (1995) Glossary of phytosanitary terms, ISPM, Publication number 5, IPPC, FAO, Rome, Italy.

Food and Agriculture Organization of the United Nations (FAO) (2005) International standards for phytosanitary measures, Guidelines for the export, shipment, import and release of biological control agents and other beneficial organisms (revision adopted at the 7th session of the ICPM, April 2005), Publication No. 3, Secretariat of the International Plant Protection Convention, FAO, Rome, Italy.

Food and Agriculture Organization of the United Nations (FAO) (2008) FAOSTAT, http://www.fao.org/faostat/foodsecurity/index_en.htm.

Fisher K. (1997) Irradiation effects in air and in nitrogen on Mediterranean fruit fly (Diptera: Tephritidae) pupae in Western Australia, J. Econ. Entomol. 90, 1609-1614.

Fisher K., Cáceres C. (2000) A filter rearing system for mass reared medfly, in: Tan K.H. (Ed.), Area-Wide Control of Fruit Flies and Other Insect Pests, Proceedings of an International Conference on Area-Wide Control of Insect Pests, and the 5th International Symposium on Fruit Flies of Economic Importance, 28 May-5 June 1998, Penang, Malaysia, Penerbit Universiti Sains Malaysia, Pulau Pinang, Malaysia, pp. 543-550.

Follet P.A., Duan J.J. (2000) Non-target effects of biological control, Kluwer Academic Publishers, Dordrecht, The Netherlands.

Ford J., Nash T.A.M., Welch J.R. (1970) Control by clearing of vegetation, in: Mulligan H.W. (Ed.), The African trypanosomiasis, Allen and Unwin Ltd, London, UK, pp. 543-556.

Franz G. (2005) Genetic sexing strains in Mediterranean fruit fly, an example for other species amenable to large-scale rearing for the sterile insect technique, in: Dyck V.A., Hendrichs J., Robinson A.S. (Eds.), Sterile insect technique. Principles and practice in area-wide integrated pest management, Springer, Dordrecht, The Netherlands, pp. $427-251$.

Franz G., Gencheva E., Kerremans P. (1994) Improved stability of genetic sex-separation strains for the Mediterranean fruit fly, Ceratitis capitata, Genome 37, 72-82.
Genchev N.P., Michelva-Dimitrova R.Y., Kozhuharova M.V. (2007) Use of gamma radiation for suppression of the hemocytic immune response in larvae of Galleria mellonella (Lepidoptera) against Venturia canescens (Hymenoptera), J. Balkan Ecol. 10, 411-419.

Gonzalez J., Troncoso P. (2007) The fruit fly exclusion programme in Chile, in: Vreysen M.J.B., Robinson A.S., Hendrichs J. (Eds.), Area-wide control of insect pests. From research to field implementation, Springer, Dordrecht, The Netherlands, pp. 614-651.

Hamed M., Nadeem S., Riaz A. (2009) Use of gamma radiation for improving the mass-production of Trichogramma chilonis and Chrysoperla carnea, Bio. Sci. Tech. 19, S1, 43-48.

Hamilton G. (2000) When good bugs turn bad, New Scientist, 30-33.

Hendrichs J., Franz G., Rendón P. (1995) Increased effectiveness and applicability of the sterile insect technique through male-only releases for control of Mediterranean fruit flies during fruiting seasons, J. Appl. Entomol. 119, 371-377.

Hendrichs J., Kenmore P., Robinson A.S., Vreysen M.J.B. (2007) Areawide integrated pest management (AW-IPM): principles, practice and prospects, in: Vreysen M.J.B., Robinson A.S., Hendrichs J. (Eds.), Area-wide control of insect pests. From research to field implementation, Springer, Dordrecht, The Netherlands, pp. 3-33.

Hendrichs J., Vreysen M.J.B., Enkerlin W.R., Cayol J.P. (2005) Strategic options in using sterile insects for area-wide integrated pest management, in: Dyck V.A., Hendrichs J., Robinson A.S. (Eds.), Sterile insect technique. Principles and practice in area-wide integrated pest management, Springer, Dordrecht, The Netherlands, pp. 563600.

Hendrichs J., Bloem K.A., Hoch G., Carpenter J.E., Greany P., Robinson A.S. (2009) Improving the cost-effectiveness, trade and safety of biological control for agricultural insect pests using nuclear techniques, Bio. Sci. Tech. 19, 3-22.

Herren H.R., Neuenschwander P., Hennesey R.D., Hammond W.N.O. (1987) Introduction and dispersal of Epidinocarsis lopezi (Hym., Encyrtidae), an exotic parasitoid of the cassava mealybug, Phenacoccus manuhoti (Hom., Pseudococcidae), Africa, Agric. Ecosyst. Environ. 19, 131-144.

Herren H.R., Neuenschwander P. (1991) Biological control of cassava pests in Africa, Annu. Rev. Entomol. 36, 257-283.

Hokkanen H.M.T., Lynch J.M. (1996) Biological control - benefits and risks, Cambridge University Press, UK.

Hooper G.H.S. (1989) The effect of ionizing radiation on reproduction, in: Robinson A.S., Hooper G. (Eds.), World crop pests, Vol. 3A, Fruit flies, their biology, natural enemies and control, Elsevier, Amsterdam, The Netherlands, pp. 153-164.

International Atomic Energy Agency (IAEA) (2008) Model business plan for a sterile insect production facility, 978-92-0-110007-8, IAEA,Vienna, Austria.

International Atomic Energy Agency/ Food and Agriculture Organization of the United Nations (IAEA/FAO) (1997) Control of the Mediterranean fruit fly in the Near East region using the sterile insect technique, STI/PUB/1020, IAEA, Vienna, Austria.

Klassen W. (2005) Area-wide integrated pest management and the sterile insect technique, in: Dyck V.A., Hendrichs J., Robinson A.S. (Eds.), Sterile insect technique, Principles and practice in area-wide integrated pest management, Springer, Dordrecht, The Netherlands, pp. 39-68.

Klassen W., Creech J.P. (1973) Population suppression with dominant and conditional lethal mutations; some important considerations and approaches, in: Computer models and application for the sterile male technique, IAEA, Vienna, Austria, pp. 65-79.

Knipling E.F. (1955) Possibilities of insect population control through the use of sexually sterile males, J. Econ. Entomol. 48, 443-448. 
Knipling E.F. (1959) The sterile male method of population control, Science 130, 902-904.

Knipling E.F. (1960) The eradication of the screwworm fly, Sci. Am. 203, 54.

Knipling E.F. (1966) Some basic principles in insect population suppression, Bull. Entomol. Soc. Am. 12, 7-15.

Knipling E.F. (1972) Entomology and the management of man's environment, J. Aust. Entomol. Soc. 11, 153-167.

Knipling E.F. (1979) The basic principles of insect population suppression and management, Agriculture Handbook Number 512, SEA, USDA, Washington DC, USA.

Knipling E.F. (1992) Principles of insect parasitism analyzed from new perspectives: practical implications for regulating insect populations by biological means, USDA Agriculture Handbook No. 693, USA.

Koul O., Cuperus G., Elliott N. (2008) Areawide pest management. Theory and implementation, Cab International, UK.

Kovaleski A., Mumford J. (2007) Pulling out the evil by the root; the codling moth Cydia pomonella eradication programme in Brazil, in: Vreysen M.J.B., Robinson A.S., Hendrichs J. (Eds.), Areawide control of insect pests. From research to field implementation, Springer, Dordrecht, The Netherlands, pp. 581-590.

Koyama T., Kakinohana H., Miyatake T. (2004) Eradication of the melon fly Bactrocera cucurbitae in Japan: importance of behaviour, ecology, genetics and evolution, Annu. Rev. Entomol. 49, 331-349.

Krafsur E. (1998) Sterile insect technique for suppressing and eradicating insects; 50 years and counting, J. Agric. Entomol. 15, 303-317.

Kuznetsova V.G., Petropavlovskaia M.B. (1976) Behaviour of holokinetic chromosomes in the spermatogenesis of bugs, Tsitologiia 18, 702711.

LaChance L.E. (1979) Genetic strategies affecting the success and economy of sterile insect release method, in: Hoy M.A., McKelvey J.J. Jr. (Eds.), Genetics in relation to insect management, Rockefeller Foundation, NY, WA, USA, pp. 8-18.

LaChance L.E. (1985) Genetic methods for the control of lepidopteran species: status and potential, ARS-28, USDA/ARS, Washington DC, USA.

LaChance L.E., Schmidt C.H., Bushland R.C. (1967) Radiation induced sterilization, in: Kilgore W.W., Doutt R.L. (Eds.), Pest control: biological, physical and selected chemical methods, Academic Press, New York, USA, pp. 147-196.

Lance D.R., McInnis D.O. (2005) Biological basis of the sterile insect technique, in: Dyck V.A., Hendrichs J., Robinson A.S. (Eds.), Sterile insect technique. Principles and practice in area-wide integrated pest management, Springer, Dordrecht, The Netherlands, pp. 69-94.

Lance D.R., McInnis D.O., Rendón P., Jackson C.G. (2000) Courtship among sterile and wild Ceratitis capitata (Diptera: Tephritidae) in field cages in Hawaii and Guatemala, Ann. Entomol. Soc. Am. 93, $1179-1185$.

Lindquist D.A., Abusowa M., Hall M.J.R. (1992) The New World screwworm in Libya: review of its introduction and eradication, Med. Vet. Entomol. 6, 2-8.

Loomans A.J.M. (2006) Regulation of invertebrate biological control agents in Europe: review and recommendations in its pursuit of a harmonised regulatory system, Report of REBECA, http://www. rebeca-net.de/downloads/.

Louda S.M., Pemberton R.W., Johnson M.T., Follett P.A. (2003) Nontarget effects: the Achilles' heel of biological control? Annu. Rev. Entomol. 48, 365-396.
(MAG/SAG) Ministerio de Agricultura/Servicio Agricola y Ganadero. (1995) Chile; a medfly-free country, Pamphlet, Government of Chile, Santiago, Chile.

Mannion C.M., Carpenter J.E., Gross H.R. (1994) Potential of the combined use of inherited sterility and a parasitoid, Archytas marmoratus (Diptera: Tachinidae) for managing Helicoverpa zea (Lepidoptera: Noctuidae), Environ. Entomol. 23, 41-46.

Marroquin R. (1985) Mass production of screwworms in Mexico, in: Symposium on eradication of the screwworm from the United States and Mexico, Proceedings of a Symposium Presented at the National Meeting of the Entomological Society of America, 913 December 1984, San Antonio, Texas, Entomological Society of America, MD, USA, pp. 31-36.

Mastro V.C. (1993) Gypsy moth $F_{1}$ sterility program: current status, in: Radiation Induced $F_{1}$ Sterility in Lepidoptera for AreaWide Control, Proceedings of the Final Research Coordination Meeting, Joint FAO/IAEA Division of Nuclear Techniques in Food and Agriculture, 9-13 September 1991, Phoenix, AZ, USA, STI/PUB/929. IAEA, Vienna, Austria, pp. 125-129.

McInnis D.O., Tam S.Y.T., Grace C., Miyashita D. (1994) Population suppression and sterility rates induced by variable sex-ratio, sterile insect releases of Ceratitis capitata (Diptera: Tephritidae) in Hawaii, Ann. Entomol. Soc. Am. 87, 231-240.

Meyer N.L. (1994) History of the Mexico-United States screwworm eradication program, Vantage Press, New York, USA.

Miyatake T., Yamagishi M. (1993) Active quality control in mass reared melon flies. Quantitative genetic aspects, in: Management of Insect Pests: Nuclear and Related Molecular and Genetic Techniques, Proceedings of an IAEA/FAO International Symposium, 19-23 October 1992, Vienna, Austria. STI/PUB/909, IAEA, Vienna, Austria, pp. 201-213.

Mumford J.D. (2005) Application of benefit/cost analysis to insect pest control using the sterile insect technique, in: Dyck V.A., Hendrichs J., Robinson A.S. (Eds.), Sterile insect technique. Principles and practice in area-wide integrated pest management, Springer, Dordrecht, The Netherlands, pp. 481-498.

Nagel P., Peveling R. (2005) Environment and the sterile insect technique, in: Dyck V.A., Hendrichs J., Robinson A.S. (Eds.), Sterile insect technique, Principles and practice in area-wide integrated pest management, Springer, Dordrecht, The Netherlands, pp. 499-524.

Nakashima Y., Hirose Y., Kinjo K. (1996) Rearing Orius sauteri (Poppius) on diet of freeze-dried larval powder of melon fly, Bactrocera cucurbitae Coquillett, Jap. J. Appl. Entomol. Zool. 40, 80-82.

North American Plant Protection Organization (NAPPO) (2008) http:// www.nappo.org/newsletter/2008/September.

Neuenschwander P. (1993) Human interactions in classical biological control of cassava and mango mealy bugs on subsistence farms in tropical Africa, in: Altieri M.A. (Ed.), Crop protection strategies for subsistence farmers, IT Publications, London, Westview Press, San Francisco, USA, pp. 143-177.

North D.T. (1967) Radiation-induced male sterility exhibited in the $P_{1}$ and $F_{1}$ generations in Lepidoptera, Rad. Res. 31, 615.

North D.T. (1975) Inherited sterility in Lepidoptera, Annu. Rev. Entomol. 20, 167-182.

North D.T., Holt G.G. (1969) Population suppression by transmission of inherited sterility to progeny of irradiated cabbage looper, Trichoplusia ni, Can. Entomol. 101, 513-520.

Parker A.G. (2005) Mass-rearing for sterile insect release, in: Dyck V.A., Hendrichs J., Robinson A.S. (Eds.), Sterile insect technique. Principles and practice in area-wide integrated pest management, Springer, Dordrecht, The Netherlands, pp. 209-232. 
Parker A.G., Mehta K. (2007) Sterile insect technique: a model for dose optimization for improved sterile insect quality, Fla. Entomol. 90, 88-95.

Pimentel D. (2007) Area-wide pest management: environmental, economic and food issues, in: Vreysen M.J.B., Robinson A.S., Hendrichs J. (Eds.), Area-wide control of insect pests. From research to field implementation, Springer, Dordrecht, The Netherlands, pp. 35-47.

Proverbs M.D. (1962) Progress on the use of induced sexual sterility for the control of codling moth Carpocapsa pomonella (L.) (Lepidoptera: Olethreutidae), Proc. Entomol. Soc. Ontario 92, 511

Proverbs M.D., Newton J.R., Campbell C.J. (1982) Codling moth: a pilot programme of control by sterile insect release in British Columbia, Can. Entomol. 114, 363-376.

Rendón P., McInnis D., Lance D., Stewart J. (2000) Comparison of medfly-male only and bisexual releases in large scale field trials, in: Tan K.H. (Ed.), Area-Wide Control of Fruit Flies and Other Insect Pests, Proceedings of an International Conference on Area-Wide Control of Insect Pests, and the 5th International Symposium on Fruit Flies of Economic Importance, 28 May-5 June 1998, Penang, Malaysia, Penerbit Universiti Sains Malaysia, Pulau Pinang, Malaysia, pp. 517-525.

Rendón P., McInnis D., Lance D., Stewart J. (2004) Medfly (Diptera: Tephritidae) genetic sexing: large scale field comparison of malesonly and bisexual sterile fly releases in Guatemala, J. Econ. Entomol. 97, 1547-1553.

Reuters (2008) http://www.reuters.com/article/environmentNews/ idUSTRE49N38O20081024.

Robinson A.S. (2002) Mutations and their use in insect control, Mut. Res. $511,113-132$.

Robinson A.S., Hendrichs J. (2005) Prospects for the future development and application of the sterile insect technique, in: Dyck V.A., Hendrichs J., Robinson A.S. (Eds.), Sterile insect technique. Principles and practice in area-wide integrated pest management, Springer, Dordrecht, The Netherlands, pp. 727-760.

Rössler Y. (1979) The genetics of the Mediterranean fruit fly: a "white pupae" mutant, Ann. Entomol. Soc. Am. 72, 583-585.

Runner G.A. (1916) Effect of röntgen rays on the tobacco, or cigarette beetle and the results of experiments with a new form of röntgen tube, J. Agric. Res. 6, 383-388.

Sakurai H., Murakami Y., Kohama T., Teruya T. (2000) Sterilizing mechanism of gamma-radiation in the female of West Indian potato weevil, Euscepes postfasciatus, Res. Bull. Fac. Agric. Gifu University, Japan 65, 13-20.

Seth R.K., Barik T.K., Chauhan S. (2009) Interactions of entomopathogenic nematodes Steinernema glaseri (Rhabditida: Steinernematidae) cultured in irradiated hosts, with $\mathrm{F}_{1}$ sterility: towards management of a tropical pest Spodoptera litura (Fabr.) (Lepidoptera: Noctuidae), Bio. Sci. Tech. 19, 139-155.

Simmons G., Carpenter J.E., Suckling D.M., Addison M., Dyck V.A., Vreysen M.J.B. (2010) Improved quality management to enhance the efficacy of the sterile insect technique for lepidopteran pests. J. Appl. Entomol. 134, 261-273.

Suckling D.M., Barrington A.M., Chhagan A., Stephens A.E.A., Burnip G.M., Charles J.G., Wee S.L. (2007) Eradication of the Australian painted apple moth Teia anartoides in New Zealand: trapping, inherited sterility and male competitiveness, in: Vreysen M.J.B., Robinson A.S., Hendrichs J. (Eds.), Area-wide control of insect pests. From research to field implementation, Springer, Dordrecht, The Netherlands, pp. 603-615.

Staten R.L., Rosander R.W., Keaveny D.F. (1993) Genetic control of cotton insects: the pink bollworm as a working programme, in: Management of Insect Pests; Nuclear and Related Molecular and
Genetic Techniques, Proceedings of a Symposium Organised by the FAO and IAEA, 19-23 October 1992, Vienna, Austria, IAEA, Vienna, Austria, pp. 269-284.

Toledo J., Rull J., Oropeza A., Hernández E., Liedo P. (2004) Irradiation of Anastrepha obliqua (Diptera: Tephritidae) revisited: optimizing sterility induction, J. Econ. Entomol. 97, 383-389.

Tween G. (2002) MOSCAMED-Guatemala: an evolution of ideas, in: Barnes B.N. (Ed.), Proceedings of the 6th International Symposium on Fruit Flies of Economic Importance, 6-10 May 2002, Stellenbosch, South Africa, Isteg Scientific Publications, Irene, South Africa, pp. 119-126.

United Press International (2008) http://www.upi.com/Science_ News/2008/12/19/EU_to_ban_most_aerial_crop_spraying/ UPI-94951229708407/.

US Working Group on the Food Crisis (2009) http://www. usfoodcrisisgroup.org/.

Vale G.A., Torr S.J. (2005) User-friendly models of the costs and efficacy of tsetse control: application to sterilizing and insecticidal techniques, Med. Vet. Entomol. 19, 293-305.

Van Borstel R.C. (1962) Effects of radiation on germ cells of insects: dominant lethals, gamete inactivation and gonial-cell killing, in: Radiation and Radioisotopes Applied to Insects of Agricultural Importance, Proceedings of a Symposium organised by FAO/IAEA, Athens, IAEA, Vienna, Austria, pp. 367-384.

Van der Vloedt A.M.V., Taher M., Tenabe S.O. (1978) Effect of gamma radiation on the tsetse fly Glossina palpalis palpalis (Rob. Desv.) (Diptera: Glossinidae) with observations on the reproductive biology, Int. J. Appl. Radiat. Isot. 29, 713-716.

van Driesche R., Hoddle M., Center T. (2008) Control of pests and weeds by natural enemies, Wiley-Blackwell, USA.

van Lenteren J.C., Bale J., Bigler F., Hokkanen H.M.T., Loomans A.J.M. (2006) Assessing risks of releasing exotic biological control agents of arthropod pests, Annu. Rev. Entomol. 51, 609-634.

Vargas-Terán M., Hofmann H.C., Tweddle N.E. (2005) Impact of screwworm eradication programmes using the sterile insect technique, in: Dyck V.A., Hendrichs J., Robinson A.S. (Eds.), Sterile insect technique. Principles and practice in area-wide integrated pest management, Springer, Dordrecht, The Netherlands, pp. 629-650.

Vreysen M.J.B. (1995) Radiation induced sterility to control tsetse flies. The effect of ionising radiation and hybridisation on tsetse biology and the use of the sterile insect technique in integrated tsetse control, Ph.D. dissertation, Wageningen Agricultural University, Wageningen, The Netherlands.

Vreysen M.J.B. (2005) Monitoring sterile and wild insects in areawide integrated pest management programmes, in: Dyck V.A., Hendrichs J., Robinson A.S. (Eds.), Sterile insect technique. Principles and practice in area-wide integrated pest management, Springer, Dordrecht, The Netherlands, pp. 325-361.

Vreysen M.J.B., Van der Vloedt A.M.V. (1995) Radiation sterilisation of Glossina tachinoides Westw. pupae: 1. The effect of dose fractionation and nitrogen during irradiation in the mid-pupal phase, Rev. Elev. Méd. Vét. Pays Trop. 48, 45-51.

Vreysen M.J.B., Barclay H.J., Hendrichs J. (2006a) Modeling of preferential mating in area-wide control programs that integrate the release of strains of sterile males-only or both sexes, Ann. Entomol. Soc. Am. 99, 607-616.

Vreysen M.J.B., Hendrichs J., Enkerlin W. (2006b) The sterile insect technique as a component of sustainable area-wide integrated pest management of selected horticultural insect pests, J. Fruit Ornam. Plant Res. 14, 107-131.

Vreysen M.J.B., Gerardo-Abaya J., Cayol J.P. (2007b) Lessons from area-wide integrated pest management (AW-IPM) programmes with an SIT component: an FAO/IAEA perspective, in: Vreysen 
M.J.B., Robinson A.S., Hendrichs J. (Eds.), Area-wide control of insect pests. From research to field implementation, Springer, Dordrecht, The Netherlands, pp. 723-744.

Vreysen M.J.B., Robinson A.S., Hendrichs J. (2007a) Area-wide control of insect pests, From research to field implementation, Springer, Dordrecht, The Netherlands.

Vreysen M.J.B., Saleh K.M., Ali M.Y., Abdullah M.A., Zhu Z-R., Juma K.G., Dyck V.A., Msangi A.R., Mkonyi P.A., Feldmann H.U. (2000) Glossina austeni (Diptera: Glossinidae) eradicated on the island of Unguja (Zanzibar), using the sterile insect technique, J. Econ. Entomol. 93, 123-135.

Vreysen M.J.B., Van der Vloedt A.M.V., Barnor H. (1996) Comparative gamma radiation sensitivity of Glossina tachinoides Westw., Glossina fuscipes fuscipes Newst. and Glossina brevipalpis Newst. (Diptera, Glossinidae), Int. J. Radiat. Biol. 69, 67-74.

Wajnberg E., Scott J.K., Quimby P. (2001) Evaluating indirect ecological effects of biological control, CABI Publishing, CAB International, Oxon, UK.

Walters M.L., Staten R.T., Roberson R.C. (2000) Pink bollworm integrated management using sterile insects under field trial conditions, Imperial Valley, California, in: Tan K.H. (Ed.), Area-Wide Control of Fruit Flies and Other Insect Pests, Proceedings of an
International Conference on Area-Wide Control of Insect Pests, and the 5th International Symposium on Fruit Flies of Economic Importance, 28 May-5 June 1998, Penang, Malaysia, Penerbit Universiti Sains Malaysia, Pulau Pinang, Malaysia, pp. 201-206.

Wong T.T.Y., Ramadan M.M., Herr J.C., McInnis D.O. (1992) Suppression of the Mediterranean fruit fly population with concurrent parasitoid and sterile fly releases in Kula, Maui, Hawaii, J. Econ. Entomol. 85, 1671-1681.

Wyss J. (2000) Screwworm eradication in the Americas - an overview, in: Tan K.H. (Ed.), Area-Wide Control of Fruit Flies and Other Insect Pests, Proceedings of an International Conference on AreaWide Control of Insect Pests, and the 5th International Symposium on Fruit Flies of Economic Importance, 28 May-5 June 1998, Penang, Malaysia, Penerbit Universiti Sains Malaysia, Pulau Pinang, Malaysia, pp. 79-86.

Zapater M.C., Andiarena C.E., Pérez Camargo G., Bartoloni N. (2009) Use of irradiated Musca domestica pupae to optimize mass rearing and commercial shipment of the parasitoid Spalangia endius (Hymenoptera: Pteromalidae), Bio. Sci. Tech. 19, S1, 261-270.

Zeddies J., Schaab R.P., Neuenschwander P., Herren H.R. (2001) Economics of biological control of cassava mealybug in Africa, Agric. Econ. 24, 209-219. 